\title{
Inter and intra-specific growth and domoic acid production in relation to nutrient ratios and concentrations in Pseudo- nitzschia : phosphate an important factor
}

\author{
Lema Anais Kimberley ${ }^{1,{ }^{*}}$, Latimier Marie ${ }^{1}$, Nézan Elisabeth ${ }^{2}$, Fauchot Juliette ${ }^{3,4}$, Le Gac Mickael ${ }^{1}$
}

${ }^{1}$ Ifremer, DYNECO PELAGOS, F-29280 Plouzané, France

${ }^{2}$ IFREMER, Station de Biologie Marine, Place de la Croix, BP 40537, F-29185 Concarneau Cedex, France

${ }^{3}$ Normandie University, UNICAEN, 14000 Caen, France

${ }^{4}$ UMR BOREA, CNRS-7208, IRD-207, MNHN, UPMC, UCBN, 14032 Caen, France

* Corresponding author : Kimberley A. Lema, email address : aklema@hawaii.edu

\begin{abstract}
:
The factors responsible for inducing the synthesis of toxins and responses from toxic phytoplankton blooms remain unclear. In this study we compare the influence of genotypic (at both the intra and interspecific levels) and environmental factors (nutrient concentration and ratio) on growth (in terms of cell densities) and domoic acid (DA) production in three Pseudo-nitzschia species: $P$. australis, P.pungens and P.fradulenta. A strong phosphate effect was detected. More precisely, a low initial concentration in phosphate, even at high initial nitrogen and silicate concentrations, induced the highest DA concentrations and the lowest cell densities in all strains/species studied. In contrast, a low initial concentration of nitrogen and silicate combined, with a higher phosphate concentration resulted in low cell densities, but without high DA production. Inter-species effects were also observed in DA production, where $P$. australis represented the most toxigenic species of all. Intra-specific variations were only moderate, except for a recently isolated $P$. australis strain, suggesting the influence of time since isolation on the physiology and DA production of Pseudo-nitzschia species. Overall, the lack of strong interaction between environmental and genotypic factors showed that the various genotypes investigated did not extensively diverge in their ability to respond (in terms of DA production and cell densities) to contrasting nutrient supply.
\end{abstract}

Keywords : Pseudo-nitzschia strains, Domoic acid, Ratio, Phosphate, Nitrogen

\section{Introduction}

Within the pelagic ecosystem, the synthesis of toxic secondary metabolites, such as domoic acid by Pseudo-nitzschia species, and their accumulation in the trophic networks generate health risks, especially for consumers of shellfish (reviewed in Trainer et al., 2012). Pseudo-nitzschia are cosmopolitan diatoms that 
53 include forty-eight species with 23 of them recently listed to produce domoic acid

54 (DA) (Teng et al, 2016; Zabaglo et al., 2016), a toxin responsible for amnesic

55 poisoning following the consumption of contaminated shellfish (reviewed in Trainer

56 et al., 2012 and Lelong et al., 2012). This amino acid is an analogue of a

57 neurotransmitter (glutamic acid) and can cause, in humans and other animals (e.g.

58 seals and birds), gastrointestinal disorders followed by neurological problems that can

59 lead to death (La Barre et al., 2014). Moreover, these toxic events have significant

60 socio-economic impacts on shellfish industries and fisheries (Belin et al., 2013).

61 However, the factors responsible for inducing the synthesis of these toxins remain

62 unclear (reviewed in Lelong et al., 2012; Trainer et al., 2012; Zabaglo et al., 2016).

Domoic acid synthesis is governed by several biotic and abiotic factors.

64 Genotypic differences (i.e inter and intra species differences), life stages, biological

65 interactions with bacteria, and abiotic environmental parameters have all appeared to

66 influence DA production (e.g. Bates et al., 1998; Maldonado et al., 2002; Kaczmarska

67 et al., 2005; Thesssen et al., 2009; Amato et al., 2010; Guannel et al., 2011; Lelong et

68 al., 2013; Lundholm et al., 2012; Sison-Mangus et al., 2014; Martin-Jézéquel et al.,

69 2015). Inter-specific differences are inferred from the fact that some species, such as

$70 \quad$ Pseudo-nitzschia australis can produce higher amounts of DA than other species in

71 particular P.pungens and P.fraudulenta (reviewed in Trainer et al., 2012). There also

72 seems to be strong intra-specific variability, but it is a relatively unexplored domain

73 (Thessen et al., 2009). Several studies have looked at the influence of environmental

74 parameters on toxin production, mainly focusing on the impact of diverse nitrogen

75 sources (e.g. mineral nitrogen $\mathrm{NO}_{3}{ }^{-}$and organic nitrogen such as urea (reviewed in

76 Martin-Jézéquel et al., 2015) and of limitation of different elements such as

77 phosphate, silicate, nitrogen and iron (Bates et al., 1991; Pan et al., 1996a, 1996b; 
Maldonado et al., 2002; Fehling et al., 2004; Lelong et al., 2013). While all these factors seem to strongly influence the production of DA, understanding the phenomenon remains very fragmented and similar studies have found different results in different parts of the world, (Bates 1998; Bates and Trainer 2006). Redfield (1934) described that phytoplankton and seawater across the oceans have a similar atomic ratio of elements of $106: 16: 1(\mathrm{C}: \mathrm{N}: \mathrm{P})$, suggesting that the ratio between nutrients is as important as their concentration, and he defined a stoichiometric equilibrium of elements. Later, Brzezinski (1985) expanded Redfield's ratio of nutrients specifically for Diatoms and included silicate $(\mathrm{Si}: \mathrm{N}: \mathrm{P}=15: 16: 1$ ratio). While it is likely more complex than previously believed, as there are substantial elemental variations among ocean taxa and environmental changes, this ratio is the most broadly applied stoichiometric reference for nutrient limitation of planktonic production (Martiny et al., 2016).

Previous studies on different Pseudo-nitzschia species showed that, when nitrogen is available, a limitation in silicate or phosphate induced an increase in DA production in cultures (Bates et al., 1991, 1998; Pan et al., 1996a, 1996b; Fehling et al., 2004). However, such studies generally only look at one nutrient parameter at a time and disregard the fate of the other nutrients. Indeed, there seems to be a lack of attention towards the effect of different N:P:Si ratios and of the limitation of one nutrient versus the other. Particularly, there are few studies looking at the effect of Phosphate availability and ratio. On another note, only a handful of studies have looked at intra-specific differences between different strains of DA producing diatoms (e.g. Thessen et al., 2009; Hagström et al, 2010). Together, these factors could explain part of the variability in studies looking at DA production. 
In the present study, we assayed the growth (in terms of cell densities at stationary phase) and DA production of nine strains from three toxigenic Pseudonitzschia species ( $P$. australis, $P$. pungens, $P$. fraudulenta) in relation to phosphate availability, considering different $\mathrm{Si}: \mathrm{N}: \mathrm{P}$ ratios (in accordance or deviating from the Redfield-Brzezinski’s stoichiometric Si:N:P = 15:16:1 ratio) (Redfield, 1934; Brzezinski 1985). Our goal was to decipher at what point Pseudo-nitzschia phenotypic responses (cell densities and DA production) were driven by genotypes, at both intra- and inter-specific levels, and/or environmental factors (phosphate availability).

\section{MATERIALS AND METHODS}

\subsection{Collection, identification and maintenance of Pseudo-nitzschia cultures} Strains of three Pseudo-nitzschia species (P. australis, P. pungens and P.

fraudulenta) were collected and isolated from different locations on the north coast of France (Normandy, English Channel) and the West Finistère coast of France (Brittany, Atlantic coast). For each species, three strains (nine strains in total) were selected for this study (Table 1).

To establish monoclonal strains, single cells were isolated using a sterile micropipette, washed three times with filter-sterilized seawater and transferred to $\mathrm{K} / 2$ + Si culture medium (Keller et al., 1987). Pseudo-nitzschia species and strains (Table 1) were identified using TEM and through sequencing of the gene ITS1-5, 8S-ITS2. ITS1 and ITS2 regions were extracted from large genome data sets for all strains (undergoing project). And all the strains from a given species had identical sequences (GenBank accession numbers KY317919-KY317921). 
Cultures were maintained in sterile-filtered oligotrophic seawater amended with $\mathrm{K} / 2+\mathrm{Si}$ medium $\left(100.8 \mu \mathrm{M} \mathrm{Na}_{2} \mathrm{SiO}_{3} .5 \mathrm{H}_{2} \mathrm{O} ; \mathrm{pH} \sim 8\right.$; salinity 33.5$)$ (modified from Keller et al., 1987) at $16^{\circ} \mathrm{C}$ and under a $12: 12 \mathrm{~L}: \mathrm{D}$ cycle and $80 \mu \mathrm{mol}$. photons.m $\mathrm{m}^{-2} \cdot \mathrm{s}^{-1}$ 129 in an algal incubator.

For cell size measurements, each strain was observed under a Nikon Eclipse 80i

131 light microscope equipped with a Nikon DS-Ri2 camera and 20 cells of each strain were measured (length and width) using NIS-Elements Imaging Software. The strain size was calculated as the mean \pm standard deviation of 20 cells measured.

\subsection{Experimental setup: varying the initial $\mathrm{Si}: N: P$ ratio}

To test the effect of initial phosphate concentration and ratio (i.e. in relation to coupled nitrate and silicate availability) on cell densities and DA concentrations, three strains from each of the 3 studied species (making a total of 9 strains; see Table 1) were grown in nine modified $\mathrm{K} / 2+\mathrm{Si}$ media, in which concentrations of $\mathrm{NaNO}_{3}$,

$140 \quad \mathrm{NaH}_{2} \mathrm{PO}_{4} \cdot \mathrm{H}_{2} \mathrm{O}$ and $\mathrm{Na}_{2} \mathrm{SiO}_{3} \cdot 5 \mathrm{H}_{2} \mathrm{O}$ varied (at $12: 12 \mathrm{~L}: \mathrm{D}$ cycle, temperature $\sim 16{ }^{\circ} \mathrm{C}$ 141 and $\mathrm{pH} \sim 8$ ) (nb: no $\mathrm{NH}_{4}$ was added, in order to have only one source of nitrogen for 142 the experiments). In our study we were primarily interested in observing the effects of

143 phosphate availability in comparison to $\mathrm{N}$ and Si. Therefore, similarly to Redfield-

144 Brezinsky stoichiometric ratio (C:Si:N:P = 106:15:16:1) initial silicate concentrations

145 were set to vary along with the variation of nitrogen (1:1 ratio). Three media consisted 146 of initial Si:N:P =16:16:1 at increasing concentrations (i.e. media M1, M5 and M9).

147 The other six (M2, M3, M4, M6, M7 and M8) were set to deviate from the Redfield-

148 Brezinsky ratio by having phosphate and/or nitrate and silicate in excess or in

149 limitation, as presented in Figure 1. Since initial nitrate and silicate concentrations 150 were equivalent in all media, they will be referred in the text as "N_Si". 
All strains and species were grown in triplicate for each of the nine experimental media, in 40-ml flasks (T25, Sarstedt AG \& Co, Nümbrecht, Germany) containing $20 \mathrm{ml}$ and a starting cell concentration of $\sim 2000$ cells. $\mathrm{ml}^{-1}$ (making a total of 243 cultures). In order to collect cells at stationary phase, growth was followed by subsampling $1 \mathrm{ml}$ of homogenized culture every two days into a 48 -well plate and quantifying in vivo chlorophyll fluorescence (ex: 440/40, em: 680/20) in a FLX800 fluorescence microplate reader (Biotek Inc., VT, USA). Samples were collected at stationary phase, 4 to 9 days after reaching maximum fluorescence (see Supplementary Fig. 1 and Supplementary Table 1 to visualize growth trends and dates of collection for each sample).

At late stationary phase, samples (all cells plus medium in the flask) were collected, snap frozen in liquid nitrogen and stored at $-80^{\circ} \mathrm{C}$. Subsamples were also fixed in Lugol's iodine (Merck, Darmstadt, Germany) for cell counts, using a Heimm cell counter and a light microscope (Olympus BX51, Japan).

\subsection{Domoic acid quantification}

Stored cultures were thawed and centrifuged at $\sim 2,000 \mathrm{~g}$ for 20 min to separate cells from the medium and therefore to distinguish particulate DA (PDA) from dissolved DA (DDA).

Particulate DA was extracted (from centrifuged Pseudo-nitzschia sp. cells) by adding $200 \mu \mathrm{l}$ of $10 \%$ methanol, sonicating on ice for 90 s (Ultrasonic processor, Sonics \& Materials Inc., CT, USA) and centrifuging for 5 min at $~ 18,000 \mathrm{~g}$ (Litaker et al., 2008). DA concentration was analyzed using a DA ELISA kit (Mercury Science, Durham, NC, USA), following the manufacturer's instructions, and measured on a 
spectrophotometer microplate reader (Multiskan Ex, Thermo Electron Corp., Vantaa,

176 Finland).

177 For DDA, no extraction was required and samples were processed directly with the

178 Mercury Science DA kit, as per the manufacturer's instructions.

DA concentrations were calculated from absorbance (OD) using the manufacturer's procedures and formulas. The detection limit was $0.01 \mathrm{ppb} \mathrm{DA}\left(\mu \mathrm{g} . \mathrm{L}^{-}\right.$ 1) in the extraction buffer.

\subsection{Statistics analysis}

Media were assigned to different groups corresponding to their phosphate and

185 N_Si concentration, as represented in Figure 1. Phosphate and N_Si concentrations were divided into three categories: low, medium and high (Fig. 1). An alternative to this nutrient level categorization would have been to categorize the media in term of initial deviation from the Redfield-Brezinsky ratio. However, the exploratory visualization of the results pointed towards a strong effect of nutrient levels and a weak effect of initial ratios. As nutrient levels and initial ratios are not independent, 191 only nutrient levels were used as explanatory variables. Cell density measurements were based on: 1) cell abundance for a single replicate and 2) end-point fluorescence units for all replicates (see above); both

194 collected at stationary phase (i.e. final time point). In accordance to these units of 195 growth, DA was defined as: 1) DA.cell ${ }^{-1}$ and 2) DA per unit of fluorescence 196 (DA.fluorescence ${ }^{-1}$ ). 
In the first model, using final cell counts as a proxy for growth (collected $\sim 4$

201 to 9 days after reaching maximum cell concentration), and quantifying DA per cell

$202(\mathrm{n}=81$, one measure per strain and per medium, the strains being considered as

203 replicates within the species): the effect of Species, P levels, N_Si levels, as well as

204 the interaction of species and P levels and of Species and N_Si levels (Model 1:

205 Species*N_Si levels + Species*P levels) on both growth and DA production were 206 tested.

In the second model, using end-point fluorescence as a proxy for growth, and 208 quantifying DA per unit of fluorescence $(n=243,3$ replicate per strain and per

209 medium): the approach was similar, but considering the Strains as random effect nested in Species (Model 2: Species*N_Si levels + Species*P levels + error(strain)). Finally, a third model was used to test statistical differences within each

212 species, using only end-point fluorescence units as a proxy for growth, and

213 quantifying DA per unit of fluorescence ( $\mathrm{n}=81$ for each species). Similar to Model 1,

214 but considering strains rather than species as the explanatory variable (Model 3:

215 Strains* N_Si levels + Strains*P levels). For all models, normality of data was checked and when necessary data were

$217 \log 10$ transformed or power transformed using the "car" package and the

218 "powertransform" function (R version 3.2.4)

\section{RESULTS}

\subsection{Nutrients that influence growth}

224 species were strong (Supplementary Fig. 2). 
225 For all three species, growth in terms of final cell concentrations and chlorophyll

226 fluorescence was highest when all nutrients were highest (i.e. for media M5, M6, M8

227 and M9). In contrast, lowest cell densities were found in low phosphate and low N_Si

228 (i.e. $\mathrm{N}$ and Si have equivalent initial concentrations; see Methods) media (for media

229 M1, M2, M3, M4, M7) (Fig. 2; Supplementary Fig.3).

Phosphate levels (P levels) had the strongest effect on cell densities $(37 \%$ of

231 the variance explained in terms of cell count, Table 2), especially because cell

232 densities were extremely limited by low phosphate concentrations (media M1, M2

233 and M3) for all species (Fig. 2). The influence of low initial N_Si levels on cell

234 densities was less dramatic (14\% of the variance explained; Table 2), especially for $P$.

235 australis and P. fraudulenta. These two species had their lowest cell densities in low-

236 phosphate media (M2 and M3; 10.7 and 12.0 cells. $\mu \mathrm{l}^{-1}$ for P. australis; 25.2 and 33.2

237 cells. $\mu \mathrm{l}^{-1}$ for $P$. fraudulenta, respectively) in comparison to low N_Si media (M4 and

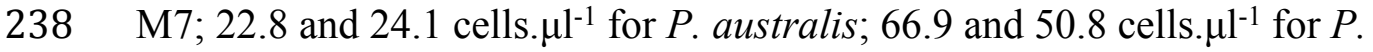

239 fraudulenta) (Fig. 2). In terms of final fluorescence (as a proxy for growth), the

240 difference between P and N_Si initial levels was less pronounced, but phosphate

241 initial levels also represented the strongest effect overall (P levels represented $29 \%$ of

242 the variance; while N_Si levels represented 22\% of the variance) (Supplementary

243 Fig.3; Supplementary Table 2) .

244 Differences in cell densities could also be observed between species (i.e the

245 species effect explained $10 \%$ of the variance explained; Table 2). More specifically,

246 P. australis presented lower densities across all media (densities ranging from 10.7 to

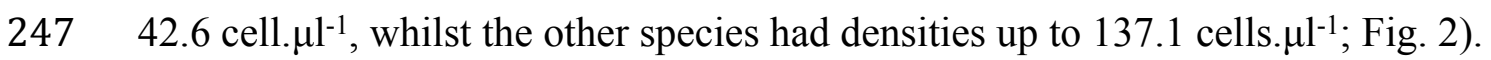

248 Similar trends were observed using end-point fluorescence as a proxy for growth

249 (Supplementary Fig. 3). 
251 among the three species were not significant (Table 2). However, we may note that

252 cell densities were rather similar in media M5, M6, M8 and M9 for $P$. australis and $P$.

253 fraudulenta, whilst $P$. pungens displayed higher cell densities in M6 and M9 than in

254 M5 and M8 (Fig.2). Similar patterns were observed for fluorescence (Supplementary

255 Fig. 3), and interaction effects (i.e fluorescence and nutrient levels) were only

256 moderate (significant interactions explained 11\% of the variance) (Supplementary

257 Table 2).

Considering intra-species variation (i.e. fluorescence used as a proxy for

growth), nutrients once again appeared to be the strongest factor contributing to

differences in cell densities within all three species (P and N_Si combined represented

26137,66 , and $75 \%$ of the variance for $P$. australis, $P$. fraudulenta and $P$. pungens,

262 respectively; Supplementary Table 3), and in general strains grew more in mediums

263 with high nutrient concentrations (i.e. media M5, M6, M8, M9) (Supplementary Fig.

264 4). There were some moderate differences amongst conspecific strains $(8,10$ and $2 \%$

265 of the variance explained in $P$. australis, $P$. fraudulenta and $P$. pungens, respectively;

266 Supplementary Table 3). However, within P. australis, one strain (Pa1) was

267 significantly different from its conspecifics, as it displayed higher cell densities in

268 media M1 and M2, and its lowest densities were found in M6 (40\% of the variance

269 was explained by a strong interaction Strain*P levels and Strain*N_Si levels together;

270 Supplementary Table 3; Supplementary Fig. 4). For P. fraudulenta and P. pungens,

271 the Strain*Media interactions were only moderate $(11 \%$ and $4 \%$ of variance explained

272 for P. fraudulenta and P. pungens, respectively; Supplementary Table 3)..

273

274 3.2. Particulate and dissolved DA 

dissolved DA (DDA)) revealed that inter-species variation was important (59\% and $52 \%$ of the variance explained using DA.cell ${ }^{-1}$ and DA.fluorescence ${ }^{-1}$, respectively; Table 2, Supplementary Table 2) and P. australis had the highest DA concentrations, with up to 0.47 pg.cell $^{-1}(+/-0.33 \mathrm{SE})$ (Fig. 3A).

When looking at DDA and PDA independently, P. pungens and P. fraudulenta

281 DDA values fell below the detection limit, whilst $P$. australis had its highest DA values in the DDA category (Fig. 3A and B,). Indeed, DDA contributed to more than $76 \%$ of the total DA concentrations in P. australis (Fig. 3A). In contrast, PDA was 284 observed in all three species. Inter-species differences were also observed in the PDA category, and the highest DA concentrations were once more found for $P$. australis (Table $2 ; 59 \%$ and $25 \%$ of the variance explained for TDA and PDA, respectively). Matching patterns were found when looking at DA per unit of fluorescence (Supplementary Fig. 5A). Intra-species variations were found between different $P$. australis strains for both TDA and PDA (Supplementary Table 3; 59\% and 25\% of the variance explained 291 for TDA and PDA, respectively). Strain Pa1 reached the highest values overall for 292 both TDA and PDA, while Pa3 had the lowest values of all three $P$. australis strains 293 (Supplementary Fig. 6). Within $P$. fraudulenta and $P$. pungens, DA production was 294 only marginally attributed to inter-strain differences $(3 \%$ and $2 \%$ of the variance explained; Supplementary Table 3) and primarily attributed to P levels (50\% and 31\%

296 of the variance explained for P. fraudulenta and P. pungens, respectively;

297 Supplementary Table 3). 
When looking at differences in DA production in relation to different nutrient

301 ratios and concentrations, P levels was the second factor (after species) affecting TDA

302 and the strongest factor for PDA (Table 2; 14\% and 27\% of the variance explained for 303 TDA and PDA, respectively). Opposite to the trends observed with cell densities (i.e.

304 high cell densities when initial N_Si and P concentrations were low), DA was highest 305 in media with low initial N_Si and P concentrations, and particularly when initial 306 phosphate was low (Fig. 3B). Indeed, for all DA categories (particulate, dissolved and 307 total) and across all species, DA was highest in the low-phosphate media M1, M2 and 308 M3 (Fig. 3). P. australis reached its highest total DA (TDA) in the low-phosphate 309 media (M1, M2 and M3), with 0.33 pg.cell ${ }^{-1}, 0.35$ pg.cell $^{-1}$ and 0.47 pg.cell $^{-1}$, respectively. Total DA levels of $P$. fraudulenta and $P$. pungens (equivalent to PDA

311 since there was no DDA for these species) were also highest in low-phosphate media, 312 (Fig. 3B). P. fraudulenta reached a maximum PDA in medium M1 (0.05 pg.cell $\left.{ }^{-1}\right)$ 313 followed by M2 and M3 (0.02 and 0.01 respectively) (Fig. 3B). P. pungens also had 314 the highest PDA concentrations in these three media $\left(0.02,0.02\right.$, and 0.01 pg.cell $\left.^{-1}\right)$. 315 Similar trends were observed when looking at DA in relation to units of fluorescence 316 (Supplementary Fig. 5B). Overall, diversity of nutrient conditions in terms of ratios 317 and concentrations examined in this study revealed that, even at similar ratios (i.e 318 N_Si: P ratios), a decrease in the concentration of phosphate (e.g media M2 and M6: 319 ratios of 53.3 and 48 , concentrations of $3 \mu \mathrm{M}$ to $10 \mu \mathrm{M}$, respectively; Fig. 1) induced 320 divergent responses: lower growth and much higher DA concentrations. Finally, the effect of the interactions between the genotypes (species or 322 strains) and environmental (N_Si levels or P levels) factors on DA production was 323 only moderate (Table 2 and Supplementary Table 2 and 3; only a few percent of the 324 variance explained). Nevertheless, the production of DA of the three species seems to 
325 follow slightly different trends in the various media. Indeed, for a given P-level, the

326 DA production of $P$. fraudulenta and $P$. pungens tends to be higher in the media with

327 low N_Si levels, while it is not the case for P. australis. This is visible when

328 investigating species specific differences (Fig.3 and Supplementary Fig. 5), but also

329 when considering the intraspecific level (N_Si levels explaining 10 and $19 \%$ of the

330 variance in TDA production within P. fraudulenta and P. pungens, but only $1 \%$

331 within P. australis, see Supplementary Table 3). This suggests that the conditions

332 favoring DA production are mainly preserved across the studied species but that slight

333 species specific differences may exist.

\section{DISCUSSION}

This study investigated the effect of genotypes (species and strains) and environmental factors on growth (i.e in terms of cell densities at stationary phase) and domoic acid (DA) production in Pseudo-nitzschia. Results indicated that growth and DA production are both affected by the environmental factors examined and predominantly by low phosphate concentrations, which resulted in lower cell densities and highest DA concentrations across all species and the majority of strains studied.

343 Growth differences between species were only moderate, but there were extreme

344 differences in toxin concentrations, and P. australis appeared to be the species with

345 the highest DA concentrations amongst the studied species. Considering strains, 346 within $P$. fraudulenta and P. pungens, cell densities and DA production were mainly 347 affected by nutrient levels, and very weakly by differences amongst strains. However, 348 within P. australis, one strain displayed very different patterns in terms of both 349 growth (cell concentrations less variable across the environments than the other 
strains) and DA production (higher toxin production than conspecific strains and

351 highest toxin production overall).

\subsection{Phosphate limitation an important factor for growth and $D A$ production}

Many studies looking at domoic acid (DA) production in Pseudo-nitzschia species have concentrated on the effect of varying nitrogen or silicate sources and limitations. Fewer have looked at the effect of phosphate and at the effect of variable Si:N:P ratios and concentrations on DA production in Pseudo-nitzschia (Pan et al., 1996a; Fehling et al., 2004; Hagström et al., 2010; Terseleer et al., 2013).

Nevertheless, previous studies found that, in some Pseudo-nitzschia species, DA production was increased under P limitation (Pan et al., 1996; Bates et al., 1998;

361 Fehling 2004). Similarly to our results, Hagström et al (2010) found that phosphate

362 deficiencies (in terms of a high N:P ratio, 290, and low phosphate concentration : 580 $363 \mu \mathrm{M} \mathrm{NaNO}_{3}$ to $2 \mu \mathrm{M} \mathrm{K}_{2} \mathrm{HPO}_{4}$ ) on two distant Pseudo-nitzschia multiseries strains (one

364 from California and one from Brazil) resulted in several fold increase in DA

365 production for both strains (Hagström et al., 2010), and, that DA was still produced 366 under $\mathrm{N}$ deficiency, but at much lower concentrations (atomic ratio N:P of 1, 367 concentrations of $36 \mu \mathrm{M} \mathrm{NaNO}_{3}, 36 \mu \mathrm{M} \mathrm{K}_{2} \mathrm{HPO}_{4}$;) (Hagström et al., 2010).

368 Importantly, the additional nutrient conditions examined in the present study

369 (different ratios and concentrations) revealed that a low concentration of phosphate

370 induced high DA concentrations and lowest cell densities regardless of the initial 371 nutrient ratio. In other words, initial $\mathrm{P}$ concentration and not initial ratio affected DA 372 concentration. In an attempt to understand the physiological mechanism by which

374 phytoplankton toxins are produced, recent studies suggested that since secondary 
metabolites share common precursors with growth, when growth is limited and photosynthesis continues, precursors are in excess and accumulate in secondary pools, where they become secondary metabolites such as DA toxins (Bates et al., 1991; Terseleer et al., 2013; Van de Waal et al., 2014; Pinna et al., 2015). With that in mind, Terseleer et al. (2013) and Bates et al. (1991) suggested the same mechanistic model for DA whereby: provided nitrogen $(\mathrm{N})$ and light are sufficient (i.e. in this instance carbon and nitrogen are accumulating in secondary pools), a limitation of $\mathrm{Si}$ or $\mathrm{P}$ favors DA production. The results of our study highlight that when $\mathrm{N}$ and $\mathrm{Si}$ are set to an initial equivalent availability, a reduction in phosphate seems to have a stronger

384 effect on DA production than a combined N and Si reduction. Previous studies 385 showed that $\mathrm{N}$ and Si are independently affecting DA production (Bates et al. 1991). Ideally, one would have separately varied N, Si and P ratio and concentrations to untangle the respective effect of these three elements. However, in our study, it was technically impossible to manage in conjunction with the nine strains investigated.

\subsection{Inter and Intra species differences}

Even though our study highlights that a limitation in phosphate favored DA production, inter and intra species differences were observed. In the present study, we

394 found that $P$. australis produced the highest DA concentrations amongst the species 395 studied. Particularly because this species released high amounts of DDA (i.e which represented the highest DA category) while the others did not (or did, but at undetectable values). P. australis is one of several ubiquitous species that are found produce DA in many places of the world, such as Europe (e.g. Cusack et al., 2002;

399 Nezán et al., 2006, 2010; Klein et al., 2010; Thorel et al., 2014), North America (e.g. 
401 Zealand (Hay et al., 2000) and South America (Sar et al., 1998). And this species has

402 been recurrently associated with high amounts of DDA (e.g. Maldonado et al., 2002;

403 Thessen et al., 2009; Martin-Jézéquel et al., 2015). On the northern west coast of

404 France, P. australis is responsible for the majority of toxic blooms in this area (Nézan 405 et al., 2006, 2010; Thorel et al., 2014). If the release of DDA is a physiological trait 406 and not only the result of cell mortality (which was not the case in our study) genetic 407 research in this domain could provide information for the mechanism used in the 408 release of this toxin.

409 In the present study, all the strains of $P$. pungens and $P$. fraudulenta studied 410 produced low quantities of DA. Both species are already considered as potentially 411 toxic but previous studies revealed an important variability in DA production within 412 these two species. Although P. fraudulenta has sometimes been found non-toxigenic 413 (Hasle 2002; Thessen et al. 2009), it has also been found capable of DA production 414 (Rhodes et al. 2013, up to 0.03 pg.cell ${ }^{-1}$; Thessen et al. 2009, up to 0.667 fg.cell $^{-1}$ ), 415 with cellular DA contents often close to detection limits. P. pungens is a species 416 characterized by an important genetic and physiological intraspecific diversity 417 (Casteleyn et al. 2008; Hubbard et al. 2008; Lim et al. 2014; Kim et al. 2015). 418 Previous studies report that some strains do not produce DA (Bates et al 1998 and 419 references therein), while some other strains can be toxigenic (Bates et al. $1998<0.1$ 420 pg.cell ${ }^{-1}$, Lelong et al. 2012 and references therein). For these two species, the DA 421 cellular concentrations measured in the present study appear in accordance with 422 previously reported cellular DA contents (Bates et al. 1998; Rhodes et al. 2013; 423 Thessen et al. 2009). 
Intra-species variability has been previously observed to be stronger than interspecies variability under different nitrogen sources (i.e. $\mathrm{NO}_{3}{ }^{-}, \mathrm{NH}_{4}{ }^{+}$and urea; Thessen et al., 2009). In our study, intra-species differences were in general only moderate. However, one $P$. australis strain, $\mathrm{Pa1}$, appeared to be different in terms of growth and DA production. Although Pa1 had the highest DA concentrations in P-limited conditions, similar cell densities and high DA concentrations were found across all media. It is important to highlight that this strain was collected only one month before the experiments began while the others had been in culture for at least one year.

433 Previous studies have highlighted that with time, cellular DA concentrations decrease 434 in culture (reviewed in Lelong et al., 2012). In addition to the age of the culture, some 435 studies suggest that DA production of Pseudo-nitzschia species may be influenced by 436 cell size (Amato et al., 2010; Lelong et al., 2012; Lundholm et al., 2012). As a result 437 of their peculiar division mode, the average diatom cell size decreases in populations 438 during vegetative multiplication, to reach a cell size threshold at which restoration of 439 large cells, via sexual reproduction, is necessary for the survival of the population 440 (Round et al., 1990; Chepurnov et al., 2004). During the present study, the $P$. 441 australis strain (Pa1) that produced the highest DA concentrations was characterized 442 by slightly larger cells compared to its conspecific strains $(56.4 \pm 1.3 \mu \mathrm{m}, 47.4 \pm 1.7$ $443 \mu \mathrm{m}$ and $48.0 \pm 2.5 \mu \mathrm{m}$, for $\mathrm{Pa} 1, \mathrm{~Pa} 2$ and $\mathrm{Pa} 3$, respectively). However, similar 444 differences in cell sizes did not seem to affect DA production among strains of $P$. 445 pungens (Pp1, $51.54 \pm 1.29$ and $\mathrm{Pp} 2,46.72 \pm 1.13$; no measure available for $\mathrm{Pp} 3)$, and 446 the two strains of P.fraudulenta measured had similar lengths (Pf1, $32.63 \pm 1.02 \mu \mathrm{m}$; 447 Pf3, $34.09 \pm 0.85 \mu \mathrm{m})$. Such results highlight that the cell size decrease alone is not 448 sufficient to explain differences in DA production, and that more profound 
449 physiological modifications linked to the culture under laboratory conditions may be 450 at play.

Finally, as mentioned previously, a strong environmental effect on both

452 growth and DA production was identified. Some conditions favored growth (high 453 nutrient supply), and some conditions favored DA production (low phosphate). The 454 inter and intra species difference were mainly observed for DA production, at both the species level, with $P$. australis producing more DA, and the strain level, with Pa1 producing more DA that the other two $P$. australis strains. No major genotype and

457 environment interaction was detected, meaning that the media in which the various 458 genotypes (species or strains) produced more DA and attained higher cell densities 459 were more or less the same. Such results illustrate that the various genotypes 460 investigated did not distinctively diverge in their ability to respond (a least in term of

461 DA production and cell densities) to contrasting nutrient supply. However, we may 462 note a slight impact of nitrate and silicate supplies on DA production for $P$.

463 fraudulenta and $P$. pungens, not found in $P$. australis. The only major exception was

464 strain Pa1, which presented a higher cell density in two of the media with a low 465 phosphate supply. But as discussed above regarding DA production, we may wonder 466 if the specificity of this strain has a genotypic, or rather a physiological basis.

\subsection{Conclusions}

The results of the present study show important inter species differences on

471 DA production: P. australis being the most toxigenic. However, the mechanism of

472 DA production control by nutrient conditions was rather similar amongst the three

473 species studied with DA production stimulated by phosphorus deficiency. In addition, 
this study demonstrates only moderate intra-specific variability, with the exception of a recently isolated $P$. australis strain, advocating for a deeper understanding of the influence of culture duration and life cycle on the physiology and DA production of Pseudo-nitzschia species.

\section{ACKNOWLEDGMENTS}

邓

We are grateful to the Ifremer LER/N staff and Eric Foucher for helping with Pseudo-nitzschia strains isolation during the 2011 COMOR Cruise in the Bay of Seine. We thank Aurore Sauvey for cell size measurements. This work was supported by a INSU EC2CO (France) grant (Pseudotox Project) and by a Ifremer/Région Bretagne (France) postdoctoral grant.

\section{The authors declare no conflict of interest}

\section{REFERENCES}

Amato, A., Lüdeking, A., Kooistra, W.H.C.F., 2010. Intracellular domoic acid production in Pseudo-nitzschia multistriata isolated from the Gulf of Naples (Tyrrhenian Sea, Italy). Toxicon 55, 157-161. doi:10.1016/j.toxicon.2009.07.005

Anderson, C., Brzezinski, M.A., Washburn, L., Kudela, R.M., 2006. Circulation and environmental conditions during a toxigenic Pseudo-nitzschia australis bloom in the Santa Barbara Channel, California. Mar. Ecol. Prog. Ser. 327, 119-133. doi:10.3354/meps327119 
Bates, S.S., 1998. Ecophysiology and metabolism of ASP toxin production. NATO ASI Ser. G Ecol. Sci. 41, 405-426.[indicate publisher]

Bates, S.S., de Freitas, A.S.W., Milley, J.E., Pocklington, R., Quilliam, M.A., Smith, J.C., Worms, J., 1991. Controls on domoic acid production by the diatom Nitzschia pungens f. multiseries in culture: nutrients and irradiance. Can. J. Fish. Aquat. Sci. 48, 1136-1144. doi:10.1139/f91-137

Bates, S.S., Trainer, V.L., 2006. The ecology of harmful diatoms, in: Granéli, E., Turner, J.T. (Eds.), Ecology of Harmful Algae, Ecological Studies. Springer Berlin Heidelberg, pp. 81-93.

Belin, C., Chapelle, A., Delmas, D., Nézan, E., Siano, R., 2013. DYNAPSE: DYNAmiques des efflorescences et de la toxicité des espèces phytoplanctoniques nuisibles du genre Pseudo-nitzschia en région LoireBretagne (http://archimer.ifremer.fr/ doc/00189/30035)

Brzezinski, M.A., 1985. The Si:C:N ratio of marine diatoms: interspecific variability and the effect of some environmental variables. J. Phycol. 21, 347-357. doi:10.1111/j.0022-3646.1985.00347.x

Casteleyn, G., Chepurnov, V.A., Leliaert, F., Mann, D.G., Bates, S.S., Lundholm, N., Rhodes, L., Sabbe, K. \& Vyverman, W. (2008). Pseudo-nitzschia pungens (Bacillariophyceae): a cosmopolitan diatom species?. Harmful Algae 7: 241257.

Chepurnov, V.A., Mann, D.G., Sabbe, K., Vyverman, W., 2004. Experimental studies on sexual reproduction in diatoms, in: Cytology, B.-I.R. of (Ed.), . Academic Press, pp. 237, 91-154).

Cusack, C.K., Bates, S.S., Quilliam, M.A., Patching, J.W., Raine, R., 2002. Confirmation of domoic acid production by Pseudo-nitzschia australis 

doi:10.1046/j.1529-8817.2002.01054.x

526 Fehling, J., Davidson, K., Bolch, C.J., Bates, S.S., 2004. Growth and domoic acid production by Pseudo-nitzschia Seriata (Bacillariophyceae) under phosphate and silicate limitation. J. Phycol. 40, 674-683. doi:10.1111/j.1529-

Guannel, M.L., Horner-Devine, M.C., Rocap, G., 2011. Bacterial community composition differs with species and toxigenicity of the diatom Pseudonitzschia. Aquat. Microb. Ecol. 64, 117-133. doi:10.3354/ame01513

Hagström, J.A., Granéli, E., Moreira, M.O.P., Odebrecht, C., 2010. Domoic acid production and elemental composition of two Pseudo-nitzschia multiseries strains, from the NW and SW Atlantic Ocean, growing in phosphorus- or nitrogen-limited chemostat cultures. J. Plankton Res. fbq102. doi:10.1093/plankt/fbq102

Hasle, G.R. 2002. Are most of the domoic acid-producing species of the diatom genus Pseudo-nitzschia cosmopolites? Harmful Algae 1, 137-146.

Hay, B.E., Grant, C.M., McCoubrey, D.-J., New Zealand, Ministry of Health, Aquabio Consultants, 2000. A review of the marine biotoxin monitoring programme for non-commercially harvested shellfish. Part 1 . Ministry of

544 Hernández-Becerril, D.U., Alonso-Rodríguez, R., Álvarez-Góngora, C., BarónCampis, S.A., Ceballos-Corona, G., Herrera-Silveira, J., del Castillo, M.E.M., Juárez-RuÍz, N., Merino-Virgilio, F., Morales-Blake, A., Ochoa, J.L., Orellana-Cepeda, E., Ramírez-Camarena, C., Rodríguez-Salvador, R., 2007. Toxic and harmful marine phytoplankton and microalgae (HABs) in Mexican 
Coasts. J. Environ. Sci. Health Part A 42, 1349-1363. doi:10.1080/10934520701480219

551

552

553

554

555

556

557

558

559

560

561

562

563

564

565

566

567

568

569

570

571

Hubbard, K. A., Rocap, G., Armbrust, E. V. 2008 Inter- and intra-specific community structure within the diatom genus Pseudo-nitzschia (Bacillariophyceae). J. Phycol. 44: 637-649

Kaczmarska, I., Ehrman, J.M., Bates, S.S., Green, D.H., Léger, C., Harris, J., 2005. Diversity and distribution of epibiotic bacteria on Pseudo-nitzschia multiseries (Bacillariophyceae) in culture, and comparison with those on diatoms in native seawater. Harmful Algae 4, 725-741. doi:10.1016/j.hal.2004.10.001

Keller, M.D., Selvin, R.C., Claus, W., Guillard, R.R.L., 1987. Media for the culture of oceanic ultraphytoplankton. J. Phycol. 23, 633-638. doi:10.1111/j.15298817.1987.tb04217.x

Kim, J.H., Park, B.S., Kim, J.H., Wang, P., Han, M.S. 2015. Intraspecific diversity and distribution of the cosmopolitan species Pseudo-nitzschia pungens (Bacillariophyceae): morphology, genetics, and ecophysiology of the three clades. J. Phycol. 51: 159-172.

Klein, C., Claquin, P., Bouchart, V., Le Roy, B., Véron, B., 2010. Dynamics of Pseudo-nitzschia spp. and domoic acid production in a macrotidal ecosystem of the eastern English Channel (Normandy, France). Harmful Algae 9, 218 226. doi:10.1016/j.hal.2009.10.004

La Barre, S., Bates, S.S., Quilliam, M.A., 2014. Domoic Acid, in: Barre, S.L., Kornprobst, J.-M. (Eds.), Outstanding Marine Molecules. Wiley-VCH Verlag GmbH \& Co. KGaA, pp. 189-216. 
Lelong, A., Hégaret, H., Soudant, P., Bates, S.S., 2012. Pseudo-nitzschia (Bacillariophyceae) species, domoic acid and amnesic shellfish poisoning: revisiting previous paradigms. Phycologia 51, 168-216. doi:10.2216/11-37.1

Lelong, A., Bucciarelli, E., Hégaret, H., Soudant, P., 2013. Iron and copper limitations differently affect growth rates and photosynthetic and physiological parameters of the marine diatom Pseudo-nitzschia delicatissima. Limnol. Oceanogr. 58, 613-623. doi:10.4319/lo.2013.58.2.0613

Lim, H.C., Lim, P.T., Teng, S.T., Bates, S.S., Leaw, C.P. 2014. Genetic structure of Pseudo-nitzschia pungens (Bacillariophyceae) populations: implications of a global diversification of the diatom. Harmful Algae 37, 142-152.

Litaker, R.W., Stewart, T.N., Eberhart, B.-T.L., Wekell, J.C., Trainer, V.L., Kudela, R.M., Miller, P.E., Roberts, A., Hertz, C., Johnson, T.A., Frankfurter, G., Smith, G.J., Schnetzer, A., Schumacker, J., Bastian, J.L., Odell, A., Gentien, P., Le Gal, D., Hardison, D.R., Tester, P.A., 2008. Rapid enzyme-linked immunosorbent assay for detection of the algal toxin domoic acid. J. Shellfish Res. 27, 1301-1310. doi:10.2983/0730-8000-27.5.1301

Lundholm, N., Bates, S.S., Baugh, K.A., Bill, B.D., Connell, L.B., Léger, C., Trainer, V.L., 2012. Cryptic and pseudo-cryptic diversity in diatoms-with descriptions of Pseudo-nitzschia hasleana sp. nov. and P. fryxelliana sp. nov. J. Phycol. 48, 436-454. doi:10.1111/j.1529-8817.2012.01132.x

Maldonado, M.T., Hughes, M.P., Rue, E.L., Wells, M.L., 2002. The effect of Fe and $\mathrm{Cu}$ on growth and domoic acid production by Pseudo-nitzschia multiseries and Pseudo-nitzschia australis. Limnol. Oceanogr. 47, 515-526. doi:10.4319/1o.2002.47.2.0515 
Martin-Jézéquel, V., Calu, G., Candela, L., Amzil, Z., Jauffrais, T., Séchet, V., Weigel, P., 2015. Effects of organic and inorganic nitrogen on the growth and production of domoic acid by Pseudo-nitzschia multiseries and P. australis (Bacillariophyceae) in culture. Mar. Drugs 13, 7067-7086. doi:10.3390/md13127055

Martiny, A.C., Talarmin, A., Mouginot, C., Lee, J.A., Huang, J.S., Gellene, A.G., Caron, D.A., 2016. Biogeochemical interactions control a temporal succession in the elemental composition of marine communities. Limnol. Oceanogr. 61, 531-542. doi:10.1002/lno.10233

Nézan, E., Antoine, E., Fiant, L., Billard, C., 2006. Identification of Pseudo-nitzschia australis and P. multiseries in the Bay of Seine. Was there a relation to presence of domoic acid in king scallops in autumn 2004? Harmful Algae News, No. 31, 1-3.

Nézan, E., Chomerat, N., Bilien, G., Boulben, S., Duval, A., Ryckaert, M., 2010. Pseudo-nitzschia australis on French Atlantic coast - an unusual toxic bloom. Harmful Algae News, No. 41, 1-2.

Pan, Y., Subba Rao, D.V., Mann, K.H., M., Brown, R.G., Pocklington, R., , 1996a. Effects of silicate limitation on production of domoic acid, a neurotoxin, by the diatom Pseudo-nitzschia multiseries. I. Batch culture studies. Mar. Ecol. Prog. Ser. 131, 225-233. doi:10.3354/meps131225

Pan, Y., Subba Rao, D.V., Mann, K.H., 1996b. Changes in domoic acid production and cellular chemical composition of the toxigenic diatom Pseudo-nitzschia multiseries under phosphate limitation. J. Phycol. 32, 371-381. doi:10.1111/j.0022-3646.1996.00371.x 
Pinna, A., Pezzolesi, L., Pistocchi, R., Vanucci, S., Ciavatta, S., Polimene, L., 2015. Modelling the stoichiometric regulation of C-rich toxins in marine dinoflagellates. PLOS ONE 10, e0139046. doi:10.1371/journal.pone.0139046

Rhodes, L., Jiang, W., Knight, B.R., Adamson, J., Smith, K., Langi, V., Edgar, M. 2013. The genus Pseudo-nitzschia (Bacillariophyceae) in New Zealand: analysis of the last decade's monitoring data. New Zealand Journal of Marine and Freshwater Research 47: 490-503.

Redfield, A. 1934. On the proportions of organic derivatives in sea water and their relation to the composition of plankton. In Daniel, R.J. ed James Johnstone Memorial Volume. University Press of Liverpool, 177-192

Round, F.E., Crawford, R.M., Mann, D.G., 1990. Diatoms: Biology and Morphology of the Genera. Cambridge University Press.

Sar, E.A., Ferrario, M.E., Castaños, C., 1998. Authentication of the type material of Pseudo-nitzschia australis Frenguelli. Diatom Res. 13, 183-185. doi:10.1080/0269249X.1998.9705443

Sison-Mangus, M.P., Jiang, S., Tran, K.N., Kudela, R.M., 2014. Host-specific adaptation governs the interaction of the marine diatom, Pseudo-nitzschia and their microbiota. ISME J. 8, 63-76.

Teng, S.T., Tan, S.N., Lim, H.C., Dao, V.H., Bates, S.S., Leaw, C.P., 2016. High diversity of Pseudo-nitzschia along the northern coast of Sarawak (Malaysian Borneo), with descriptions of P. bipertita sp. nov. and P. limii sp. nov. (Bacillariophyceae). J. Phycol. 52, 973-989. doi:10.1111/jpy.12448

Terseleer, N., Gypens, N., Lancelot, C., 2013. Factors controlling the production of domoic acid by Pseudo-nitzschia (Bacillariophyceae): A model study. Harmful Algae 24, 45-53. doi:10.1016/j.hal.2013.01.004 
645 Thessen, A.E., Bowers, H.A., Stoecker, D.K., 2009. Intra- and interspecies differences in growth and toxicity of Pseudo-nitzschia while using different nitrogen sources. Harmful Algae 8, 792-810. doi:10.1016/j.hal.2009.01.003

648 Thorel, M., Fauchot, J., Morelle, J., Raimbault, V., Le Roy, B., Miossec, C., KientzBouchart, V., Claquin, P., 2014. Interactive effects of irradiance and temperature on growth and domoic acid production of the toxic diatom Pseudo-nitzschia australis (Bacillariophyceae). Harmful Algae 39, 232-241. doi:10.1016/j.hal.2014.07.010

Trainer, V.L., Bates, S.S., Lundholm, N., Thessen, A.E., Cochlan, W.P., Adams, 655 N.G., Trick, C.G., 2012. Pseudo-nitzschia physiological ecology, phylogeny,

656 toxicity, monitoring and impacts on ecosystem health. Harmful Algae 14, 271-300. doi:10.1016/j.hal.2011.10.025

657 Van de Waal, D.B., Smith, V.H., Declerck, S.A.J., Stam, E.C.M., Elser, J.J., 2014. Stoichiometric regulation of phytoplankton toxins. Ecol. Lett. 17, 736-742. doi:10.1111/ele.12280

660 Zabaglo, K., Chrapusta, E., Bober, B., Kaminski, A., Adamski, M., Bialczyk, J., 2016. 661 Environmental roles and biological activity of domoic acid: A review. Algal Res. 13, 94-101. doi:10.1016/j.algal.2015.11.020 
668 Figure 1. Matrix diagram indicating the nutrient concentrations (i.e. phosphate, 669 nitrate, silicate) for each of the nine media (M1 to M9) used in this study. In 670 parenthesis is the nutrient ratio N_Si:P is presented (nb: M1, M5 and M9 have a N:P 671 and Si:P ratio of 16:1, and "N_Si" indicate that $\mathrm{N}$ and Si have equivalent initial 672 concentrations). The nitrogen, silicate and phosphate levels, in relation to their 673 respective concentrations, are indicated as: low, medium and high.

675 Figure 2. Growth in terms of cell abundance (cells. $\mu \mathrm{l}^{-1}$ ) at stationary phase for the 676 three species of Pseudo-nitzschia studied (all strains combined). Heat matrices 677 correspond to the nine different media, with different nutrient concentrations: $\mathrm{P}$ and

678 N_Si levels as in Figure 1; different grey shades represent low to high number of 679 cells. Average number of cells and standard errors are indicated for each medium.

681 Figure 3. Domoic acid (DA) concentrations (pg.cell-1 ${ }^{-1}$ at stationary phase for the three 682 species of Pseudo-nitzschia studied (all strains combined) growing in different media. 683 A) DA concentrations of the different species assigned to different phosphate 684 concentrations (low, medium and high), corresponding to different shades of grey. B) 685 Heat matrices, where different grey shades represent low to high concentrations of 686 DA. Average DA and standard errors are indicated for each medium. 


\section{Phosphate $(\mu \mathrm{M})$}

\begin{tabular}{|c|c|c|c|c|c|}
\hline & $\begin{array}{c}\text { (low) } \\
3 \\
\end{array}$ & $\begin{array}{c}\text { (mid) } \\
10\end{array}$ & $\begin{array}{l}\text { (high) } \\
30\end{array}$ & & \\
\hline 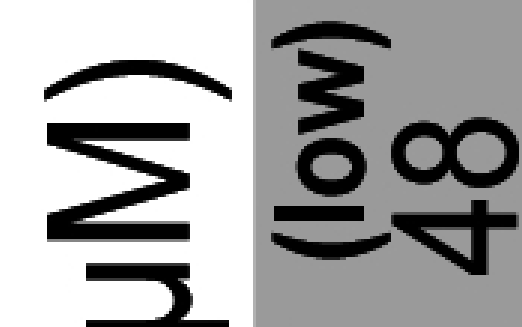 & $\begin{array}{r}\mathrm{M} 1 \\
(16)\end{array}$ & $\begin{array}{l}\text { M4 } \\
(4.8\end{array}$ & $\begin{array}{l}\text { M7 } \\
(1.6)\end{array}$ & $\stackrel{p}{\infty}$ & \\
\hline & $\begin{array}{l}\text { M2 } \\
\text { (53.3) }\end{array}$ & $\begin{array}{l}\text { M5 } \\
\text { (16) }\end{array}$ & $\begin{array}{l}\text { M8 } \\
(5.3)\end{array}$ & $\vec{\partial}$ & 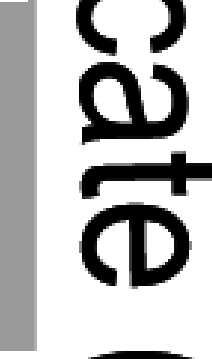 \\
\hline S & $\begin{array}{c}\mathrm{M3} \\
\text { (160) }\end{array}$ & $\begin{array}{r}\mathrm{M6} \\
(48)\end{array}$ & $\begin{array}{c}\mathrm{M9} \\
(\mathbf{1 6})\end{array}$ & 齐 & $\frac{1}{3}$ \\
\hline
\end{tabular}




\section{P. australis}

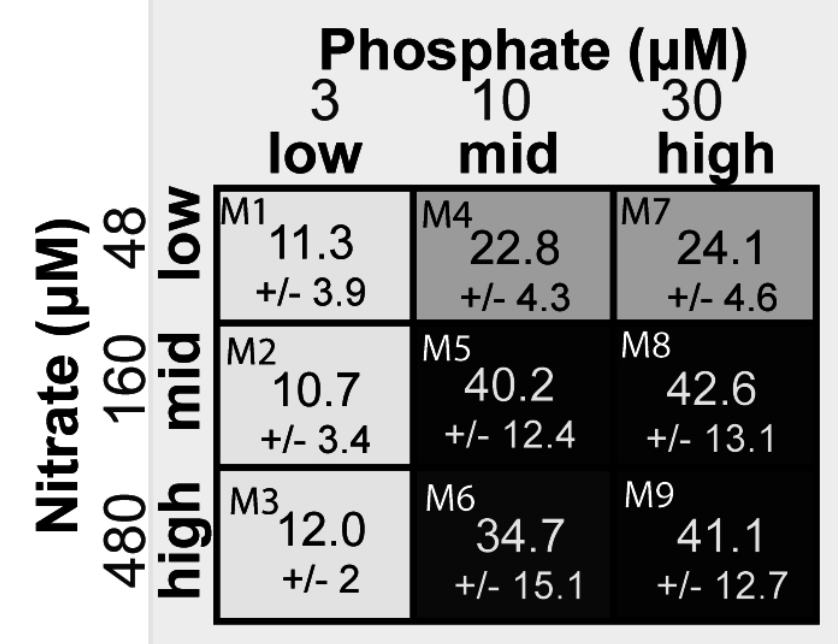

\section{P. fraudulenta}

\begin{tabular}{|c|c|c|}
\hline $\begin{array}{r}\mathrm{M} 1 \\
\quad 4.1 \\
+/-0.9\end{array}$ & $\begin{array}{r}\text { M4 } 66.9 \\
+/-19.0\end{array}$ & $\begin{array}{r}\text { M7 } \\
50.8 \\
+/-21.6\end{array}$ \\
\hline $\begin{array}{l}\text { M2 } \\
25.2 \\
+/-10.5\end{array}$ & $\begin{array}{l}\text { M5 } \\
119.1 \\
+/-36.7\end{array}$ & $\begin{array}{l}\text { M8 } \\
\quad 137.1 \\
+/-44.2\end{array}$ \\
\hline $\begin{array}{l}\text { M3 } \\
\quad 33.2 \\
+/-17.1\end{array}$ & $\begin{array}{l}\text { M6 } \\
118.2 \\
+/-32.2\end{array}$ & $\begin{array}{l}\text { M9 } \\
\quad 112.9 \\
+/-41.4\end{array}$ \\
\hline
\end{tabular}

\section{P. pungens}

\begin{tabular}{|c|c|c|c|}
\hline $\begin{array}{c}\text { Ph } \\
3 \\
\text { low }\end{array}$ & $\begin{array}{c}\text { sphate } \\
10 \\
\text { mid }\end{array}$ & $\begin{array}{c}(\mu \mathrm{M}) \\
30 \\
\text { high }\end{array}$ & \multirow[b]{2}{*}{$\stackrel{\oplus}{\infty} \underline{\underline{N}}$} \\
\hline $\begin{array}{c}\mathrm{M} 1 \\
11.1 \\
+/-1.6\end{array}$ & $\begin{array}{c}44 \\
26.3 \\
+/-2.1\end{array}$ & $\begin{array}{r}\text { M7 } 27.6 \\
+/-3.4\end{array}$ & \\
\hline $\begin{array}{c}\text { M2 } \\
38.3 \\
+/-25.5 \\
\end{array}$ & $\begin{array}{l}\text { M5 } \\
67.3 \\
+/-3.2\end{array}$ & $\begin{array}{l}\text { M8 } \\
\quad 60.5 \\
+/-0.1\end{array}$ & 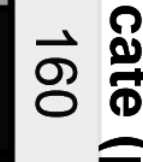 \\
\hline $\begin{array}{l}\text { M3 } \\
29.6 \\
+/-15.4\end{array}$ & $\begin{array}{l}\text { M6 } \\
131.0 \\
+/-17.0\end{array}$ & $\begin{array}{l}\text { M9 } \\
109.7 \\
+/-8.7\end{array}$ & రం \\
\hline
\end{tabular}

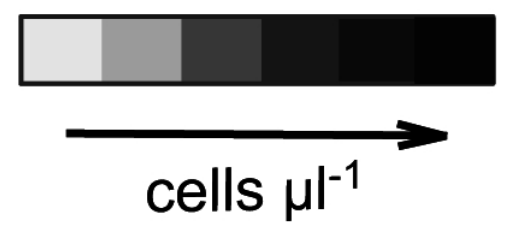


A)
P. australis
P. fraudulenta
P. pungens
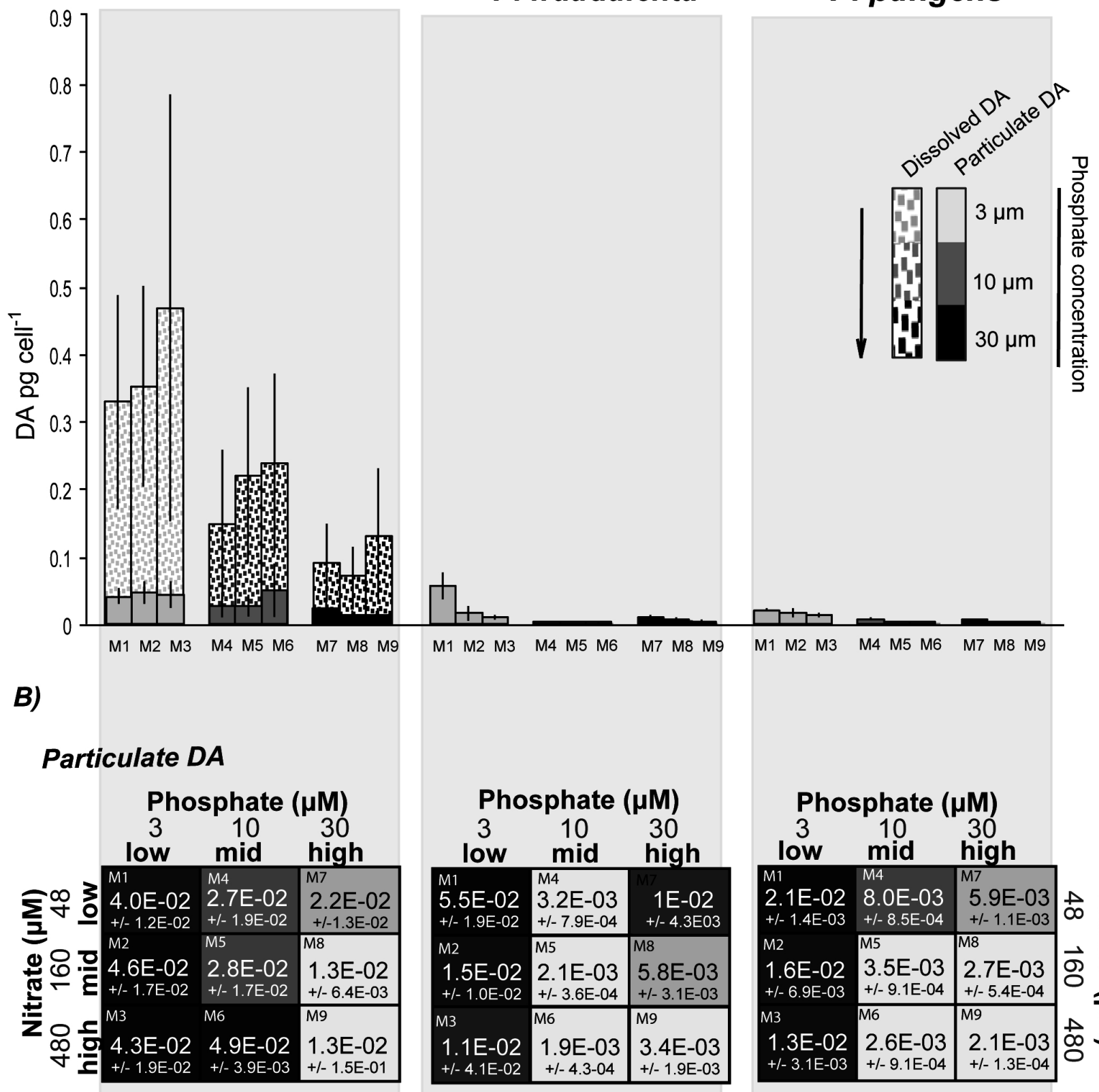

M1 M2 M3 M4 M5 M6 M7 M8 M9

M1 M2 M3 M4 M5 M6 M7 M8 M9

B)

Particulate DA

\section{Dissolved DA}

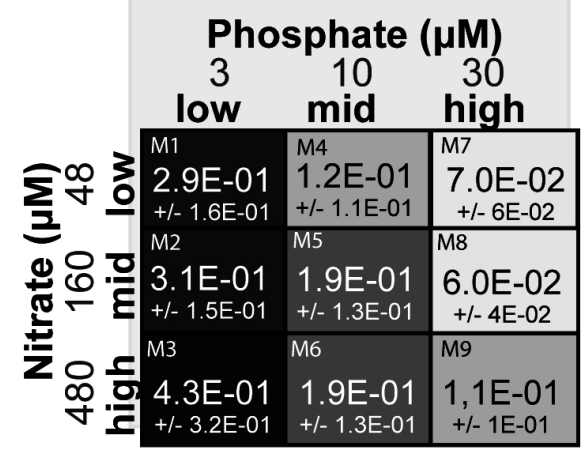

\begin{tabular}{|c|c|c|}
\hline \multicolumn{3}{|c|}{ Phosphate ( $\mu \mathrm{M})$} \\
\hline $\begin{array}{c}3 \\
\text { low }\end{array}$ & $\begin{array}{l}10 \\
\text { mid }\end{array}$ & $\begin{array}{l}30 \\
\text { high }\end{array}$ \\
\hline $\begin{array}{l}\mathrm{M} 7 \\
5.5 \mathrm{E}-02 \\
+1-1.9 \mathrm{E}-02\end{array}$ & $\begin{array}{l}\text { M4 } \\
3.2 \mathrm{E}-03 \\
+1-7.9 \mathrm{E}-04\end{array}$ & $\begin{array}{c}1 \mathrm{E}-02 \\
+/-4.3 \mathrm{E} 03\end{array}$ \\
\hline M2 & $\overline{\mathrm{M} 5}$ & M8 \\
\hline $\begin{array}{l}1.5 \mathrm{E}-02 \\
+/-1.0 \mathrm{E}-02\end{array}$ & $\begin{array}{l}2.1 \mathrm{E}-03 \\
+/-3.6 \mathrm{E}-04\end{array}$ & $\begin{array}{l}5.8 \mathrm{E}-03 \\
+/-3.1 \mathrm{E}-03\end{array}$ \\
\hline M3 & M6 & $\begin{array}{l}\mathrm{M} 9 \\
\end{array}$ \\
\hline $\begin{array}{l}1.1 \mathrm{E}-02 \\
+1-4.1 \mathrm{E}-02\end{array}$ & $\begin{array}{l}1.9 \mathrm{E}-03 \\
+/-4.3-04\end{array}$ & $\begin{array}{l}3.4 \mathrm{E}-03 \\
+/-1.9 \mathrm{E}-03\end{array}$ \\
\hline
\end{tabular}

\begin{tabular}{|c|c|c|c|}
\hline \multicolumn{3}{|c|}{$\begin{array}{c}\text { sphate } \\
10\end{array}$} & \\
\hline M1 & M4 & & \\
\hline $\begin{array}{l}2.1 \mathrm{E}-02 \\
+/-1.4 \mathrm{E}-03\end{array}$ & $\begin{array}{l}\text { 8.0E-03 } \\
+/-8.5 \mathrm{E}-04\end{array}$ & $\begin{array}{r}5.9 \mathrm{E}-03 \\
+1-1.1 \mathrm{E}-03\end{array}$ & \\
\hline M2 & M5 & $\mathrm{M} 8$ & \\
\hline $\begin{array}{l}1.6 \mathrm{E}-02 \\
++-6.9 \mathrm{E}-03\end{array}$ & $\begin{array}{l}3.5 \mathrm{E}-03 \\
+/-9.1 \mathrm{E}-04\end{array}$ & $\begin{array}{l}\text { 2.7E-03 } \\
+/-5.4 \mathrm{E}-04\end{array}$ & \\
\hline M3 & $\overline{M 6}$ & $\overline{M 9}$ & \\
\hline $\begin{array}{l}1.3 \mathrm{E}-02 \\
+/-3.1 \mathrm{E}-03\end{array}$ & $\begin{array}{l}2.6 \mathrm{E}-03 \\
+/-9.1 \mathrm{E}-04\end{array}$ & $\begin{array}{r}2.1 \mathrm{E}-03 \\
+/-1.3 \mathrm{E}-04\end{array}$ & \\
\hline
\end{tabular}

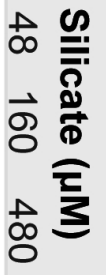



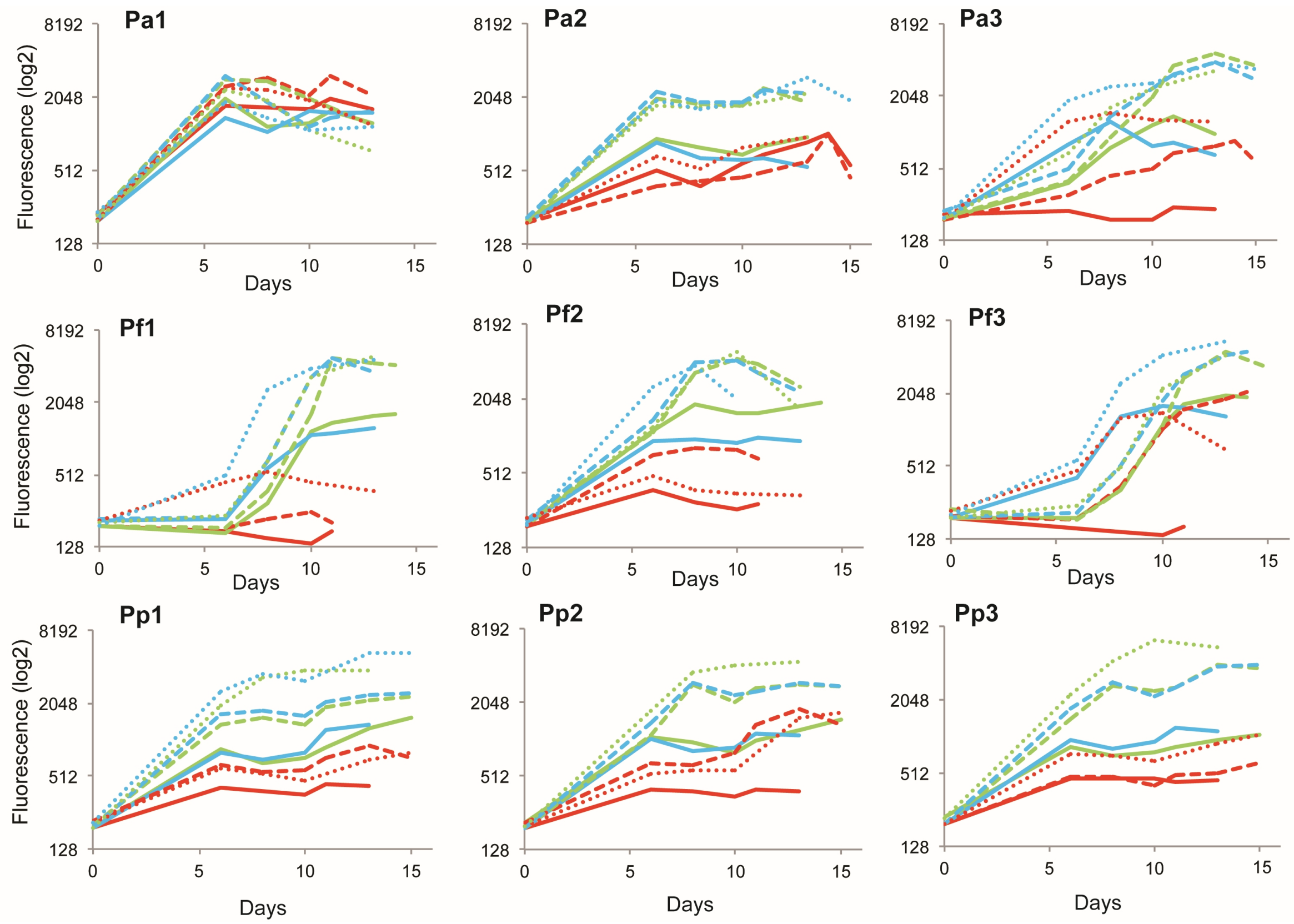


\section{All three species}

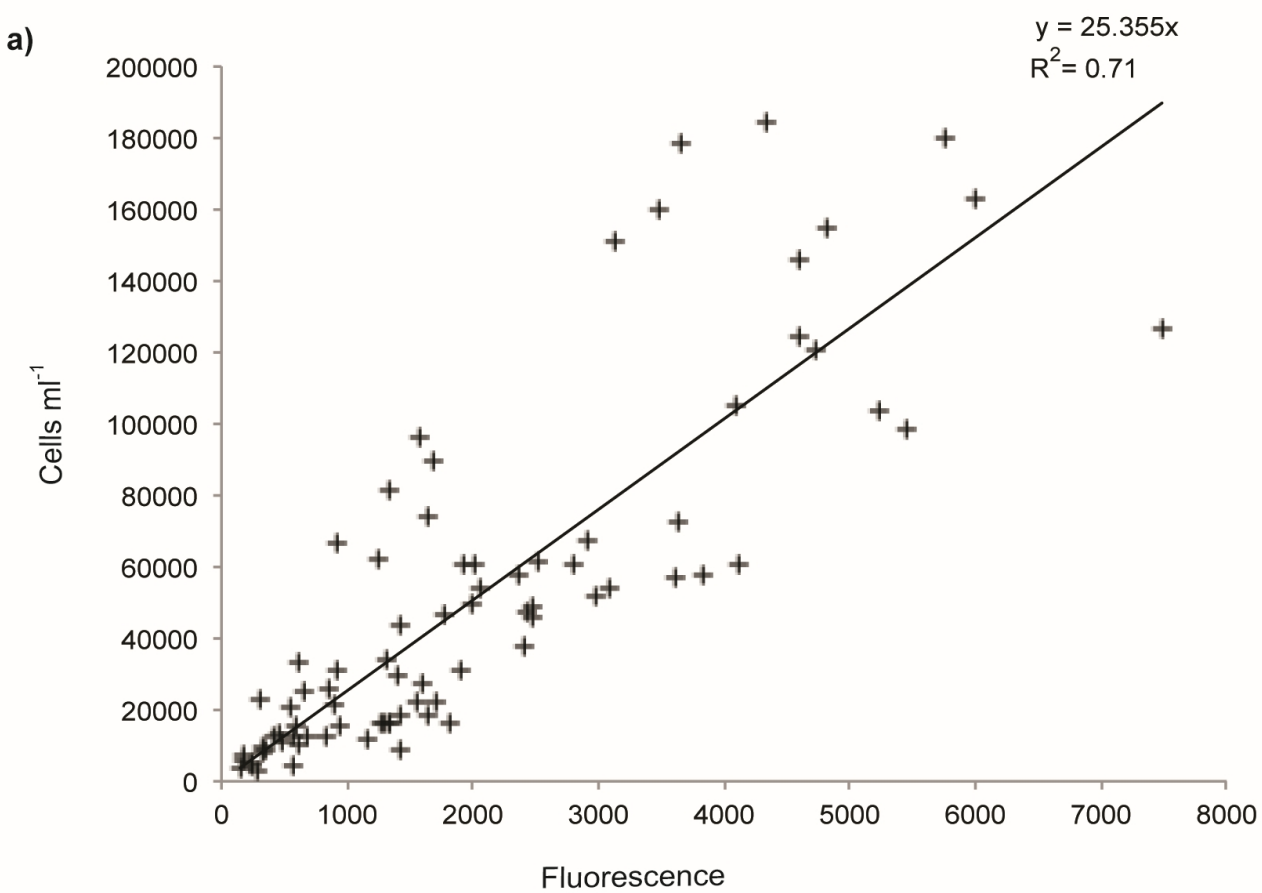

b)

\section{P. australis}

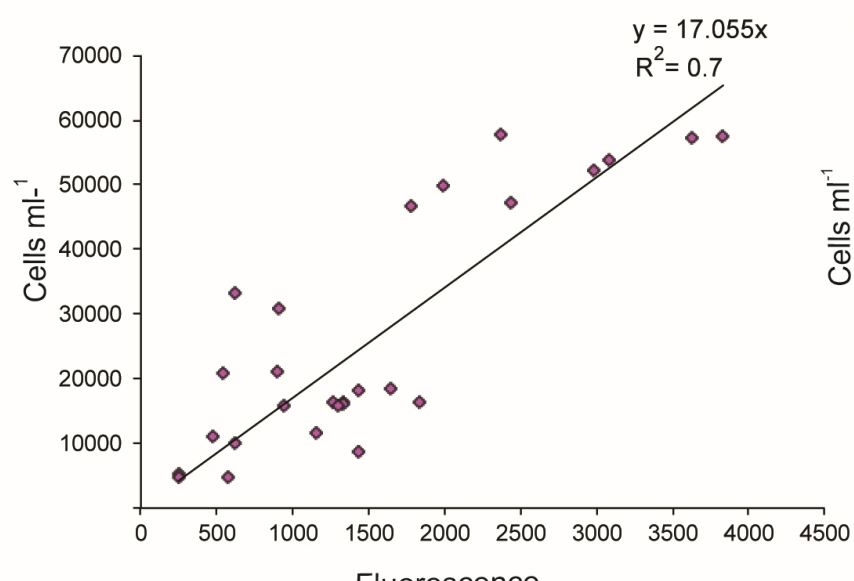

Fluorescence

\section{P. fraudulenta}

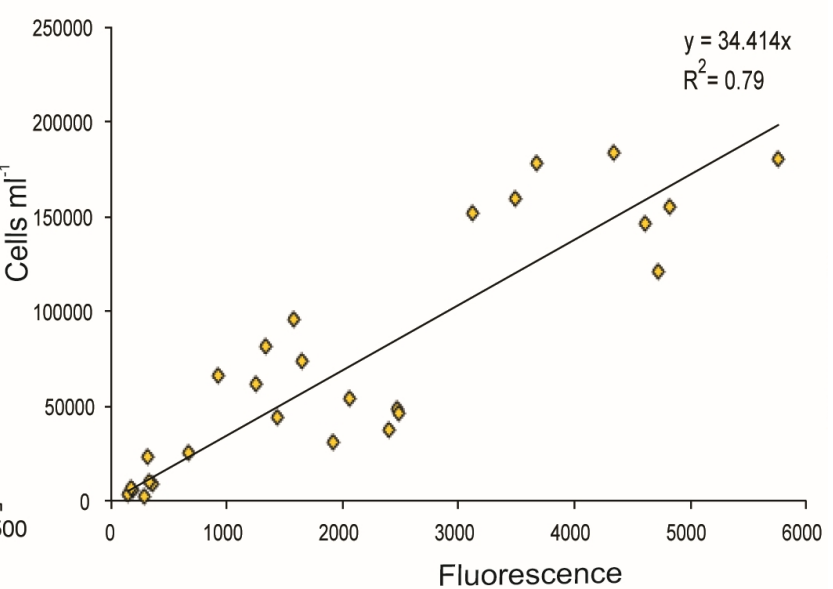

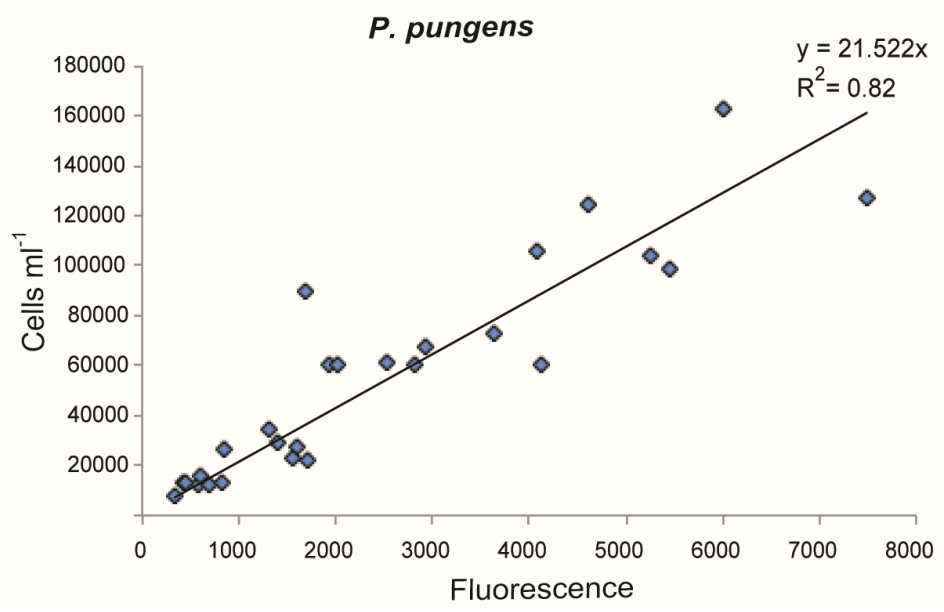




\section{P. australis}

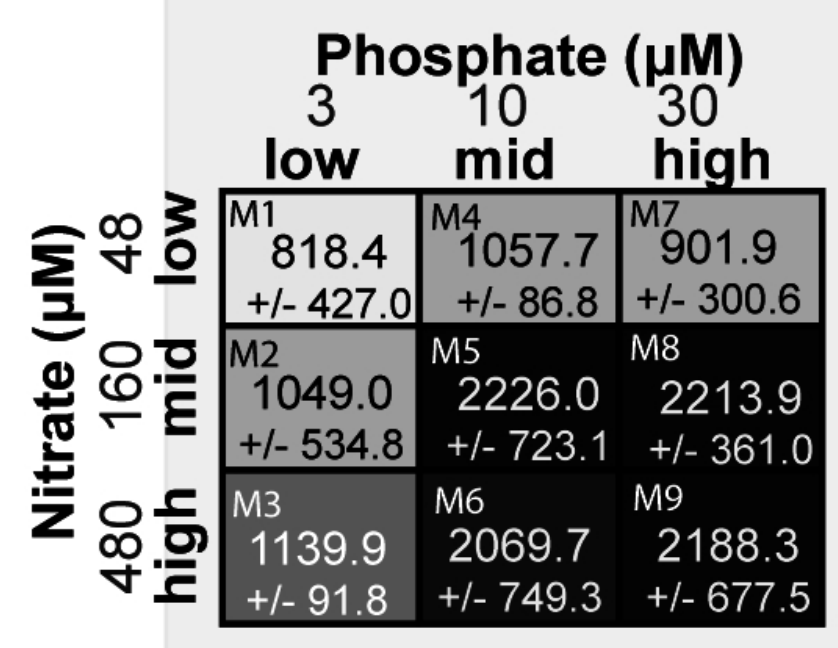

P. fraudulenta

\begin{tabular}{|c|c|c|}
\hline $\begin{array}{l}\text { Ph } \\
3 \\
\text { low } \\
\end{array}$ & $\begin{array}{l}10 \\
10 \\
\text { mid }\end{array}$ & $\begin{array}{c}\left(\mu_{I V}\right) \\
30 \\
\text { high }\end{array}$ \\
\hline \begin{tabular}{|c|} 
M1 \\
204.2 \\
$+/-39.5$ \\
\end{tabular} & $\begin{array}{l}\text { M4 } \\
1796.6 \\
+/-95.7\end{array}$ & $\begin{array}{c}1163.2 \\
+/-118.9 \\
\end{array}$ \\
\hline $\begin{array}{c}\text { M2 } \\
984.3 \\
+/-561.5 \\
\end{array}$ & $\begin{array}{l}\text { M5 } \\
3355.1 \\
+/-494.6\end{array}$ & $\begin{array}{l}\text { M8 } \\
3504.9 \\
+/-658.9\end{array}$ \\
\hline $\begin{array}{c}\text { M3 } \\
467.3 \\
+/-113.0\end{array}$ & $\begin{array}{l}\text { M7 } \\
3590.8 \\
+/-980.3\end{array}$ & $\begin{array}{l}\text { M9 } \\
\quad 4029.6 \\
+/-1004.2\end{array}$ \\
\hline
\end{tabular}

\section{P. pungens}

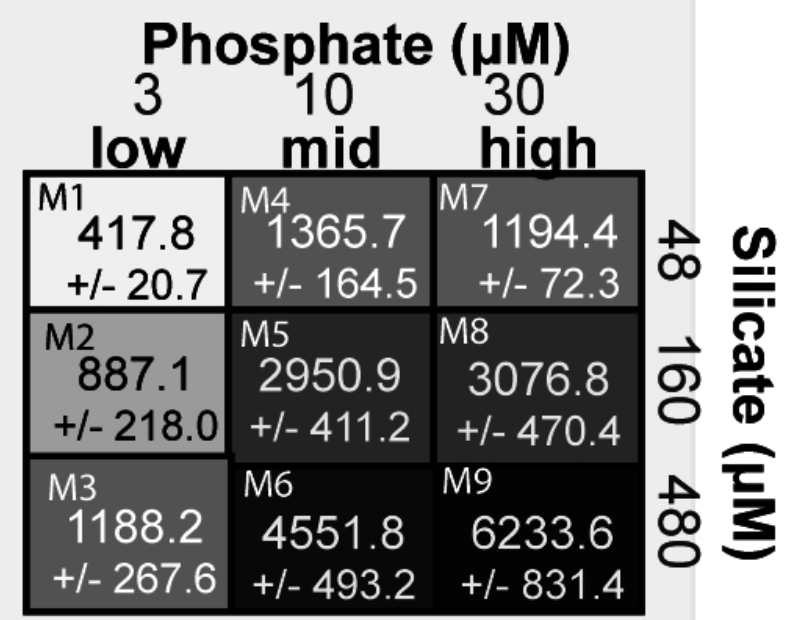

\section{Fluorescence}




\begin{tabular}{|c|c|c|c|c|c|c|c|c|c|c|}
\hline \multirow{8}{*}{ 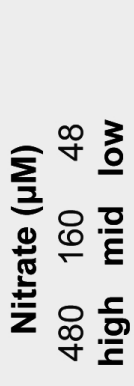 } & \multicolumn{3}{|c|}{ Phosphate $(\mu \mathrm{M})$} & \multicolumn{3}{|c|}{ Phosphate $(\mu \mathrm{M})$} & \multicolumn{4}{|c|}{ Phosphate ( $\mu \mathrm{M})$} \\
\hline & 3 & 10 & 30 & 3 & 10 & 30 & $\begin{array}{r}3 \\
\text { low }\end{array}$ & $\begin{array}{c}10 \\
\text { mid }\end{array}$ & $\begin{array}{l}30 \\
\text { high }\end{array}$ & \\
\hline & M1 & & & $\longdiv { M 1 }$ & M4 & & & & & \\
\hline & $\begin{array}{l}\mathbf{1 . 7 E + 0 3} \\
+/ 30 \mathrm{~B}+01\end{array}$ & $\begin{array}{r}1.2 \mathrm{E}+03 \\
+-91 \mathrm{~F}+01\end{array}$ & $\begin{array}{r}1.5 \mathrm{E}+\mathbf{0 3} \\
+/-7.8 \mathrm{E}+01\end{array}$ & $\begin{array}{l}5.7 E+02 \\
t-2.7 E+01\end{array}$ & $\mid \begin{array}{l}9.5 \mathrm{E}+02 \\
+1-77 \mathrm{7}+01\end{array}$ & $\begin{array}{l}5.5 E+02 \\
+t-3.5\end{array}$ & $\left|\begin{array}{c}2.3 \mathrm{E}+02 \\
+1-7.0\end{array}\right|$ & $\begin{array}{r}1.0 \mathrm{E}+03 \\
+1-5.5 \mathrm{E}+01\end{array}$ & $\begin{array}{l}\mathbf{6 . 6 E + 0 2} \\
+-3.0 \mathrm{E}+01\end{array}$ & $\infty \stackrel{p}{=}$ \\
\hline & & & & & M5 & & & & & $\bar{\S}$ \\
\hline & $2.1 \mathrm{E}+03$ & 1.2E+03 & $1.6 \mathrm{E}+03$ & $4.5 \mathrm{E}+02$ & $1.8 \mathrm{E}+03$ & $2.2 E+03$ & $\left|\begin{array}{l}5.9 \mathrm{E}+02 \\
+l-3.5 \mathrm{E}+02\end{array}\right|$ & $\begin{array}{r}3.6 E+03 \\
+l-19 E+02\end{array}$ & $\begin{array}{l}2.8 \mathrm{E}+03 \\
+l-13 \mathrm{E}+02\end{array}$ & 8 \\
\hline & & M6 & & & & & & & & 玉 \\
\hline & $\begin{array}{r}1.2 \mathrm{E}+03 \\
+-1.13 \mathrm{~F}+n)\end{array}$ & 7.3E+02 & $\begin{array}{r}1.2 E+03 \\
+-1.1 E+02\end{array}$ & $\begin{array}{l}9.6 \mathrm{E}+02 \\
+/-3.1 \mathrm{E}+01\end{array}$ & $\begin{array}{c}2.2 E+03 \\
+-2.0 E+02\end{array}$ & $\begin{array}{r}1.9 \mathrm{E}+03 \\
+t-1.4 \mathrm{E}+02\end{array}$ & $\begin{array}{l}1.2 \mathrm{E}+03 \\
+-3.3 \mathrm{E}+02\end{array}$ & $\begin{array}{r}3.3 \mathrm{E}+03 \\
+-1.7 \mathrm{E}+02\end{array}$ & $\begin{array}{r}\mathbf{3} .5 \mathrm{E}+03 \\
+-9.1 \mathrm{E}+01\end{array}$ & ఖ \\
\hline & & Pa1 & & & Pa2 & & & Pa3 & & \\
\hline
\end{tabular}

\section{P. fraudulenta}

\begin{tabular}{|c|c|c|c|c|c|c|c|c|c|c|}
\hline & Pho & sphate & $(\mu \mathrm{M})$ & Pho & sphate & $(\mu \mathrm{M})$ & Pho & sphate & $(\mu \mathrm{M})$ & \\
\hline & 3 & 10 & 30 & 3 & 10 & 30 & 3 & 10 & 30 & \\
\hline & low & mid & high & low & mid & high & low & mid & high & \\
\hline$\underline{\underline{z}}^{\infty} \stackrel{\text { 으 }}{3}$ & \begin{tabular}{|l|}
$\mathrm{M} 1$ \\
$1.7 \mathrm{E}+02$ \\
$+/-7.4$
\end{tabular} & $\begin{array}{l}\mathrm{M} 4 \\
1.6 \mathrm{E}+03 \\
+/-3.4 \mathrm{E}+01\end{array}$ & \begin{tabular}{|l|}
$\mathrm{M7}$ \\
$1.2 \mathrm{E}+03$ \\
$+/-2.2 \mathrm{E}+01$
\end{tabular} & \begin{tabular}{|c|}
$\mathrm{M} 1$ \\
$2.8 \mathrm{E}+02$ \\
$+/-2.9$
\end{tabular} & $\begin{array}{l}\mathrm{M} 4 \\
1.9 \mathrm{E}+03 \\
+l-1.9 \mathrm{E}+02\end{array}$ & $\begin{array}{l}\mathrm{M} 7 \\
\mathbf{9 . 3 E}+02 \\
+/-2.9 \mathrm{E}+02\end{array}$ & \begin{tabular}{|l|}
$\mathrm{M} 1$ \\
$1.6 \mathrm{E}+02$ \\
$+/-6.4$
\end{tabular} & $\begin{array}{l}\mathrm{M} 4 \\
1.9 \mathrm{E}+03 \\
+l-1.4 \mathrm{E}+02 \\
\end{array}$ & $\begin{array}{l}\text { M7 } \\
1.3 E+03 \\
+/-2.7 E+01\end{array}$ & $\stackrel{p}{\infty} \underline{\underline{\rho}}$ \\
\hline 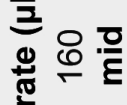 & \begin{tabular}{|l|}
$\mathrm{M} 2$ \\
$\mathbf{2} 2.1 \mathrm{E}+\mathbf{0 2}$ \\
$+/-2.9 \mathrm{E}+01$
\end{tabular} & $\begin{array}{l}+-3.4 \mathrm{E}+01 \\
\text { 45 } \\
\mathbf{4 . 2 E}+03 \\
+/-3.7 \mathrm{E}+02\end{array}$ & $\begin{array}{l}+\mid-2.2 \mathrm{E}+01 \\
\mathbf{3} 8 \\
+/-3 \mathrm{E}+03 \mathrm{E}+02\end{array}$ & $\begin{array}{l}\mathrm{M} 2 \\
6.7 \mathrm{E}+02 \\
+/-2.3 \mathrm{E}+02 \\
\end{array}$ & $\begin{array}{l}\text { M5 } \\
\mathbf{2 . 5 E}+03 \\
+/-8.1 \mathrm{E}+01\end{array}$ & $\begin{array}{l}\mathrm{M} 8 \\
2.3 \mathrm{E}+03 \\
+/-1.4 \mathrm{E}+02\end{array}$ & \begin{tabular}{|l|}
$\mathrm{M} 2$ \\
$2.1 \mathrm{E}+0.4$ \\
$+-4.7 \mathrm{E}+02$ \\
\end{tabular} & $\begin{array}{l}\text { M5 } \\
\text { 3.3E+03 } \\
+/-1.4 \mathrm{E}+02\end{array}$ & $\begin{array}{l}M 8 \\
\mathbf{4 . 5 E}+03 \\
+/-9.6 E+01\end{array}$ & न \\
\hline $\pm 0=$ & M3 & M6 & M9 & & M6 & M9 & M3 & M6 & & \\
\hline 2 舟 & $\begin{array}{r}3.7 E+02 \\
+/-8.6 E+01 \\
\end{array}$ & $\begin{array}{l}4.9 \mathrm{E}+03 \\
+/-4.8 \mathrm{E}+01\end{array}$ & $\begin{array}{l}4.6 E+03 \\
+/-4.0 E+01\end{array}$ & $\begin{array}{r}3.4 \mathrm{E}+02 \\
+/-7.5 \mathrm{E}+01\end{array}$ & $\begin{array}{r}1.7 E+03 \\
+/-2.1 E+02\end{array}$ & $\begin{array}{l}\mathbf{2 . 0 E}+\mathbf{0 3} \\
+/-2.5 E+02\end{array}$ & $\begin{array}{r}\mathbf{6 . 9 E}+02 \\
+/-1.9 \mathrm{E}+02 \\
\end{array}$ & $\begin{array}{l}\mathbf{4 . 2 E}+03 \\
+/-2.1 \mathrm{E}+02\end{array}$ & $\begin{array}{l}\mathbf{5 . 4 E}+\mathbf{0 3} \\
+/-1.7 \mathrm{E}+02\end{array}$ & $\infty$ \\
\hline & & 1 & & & Pf? & & & f3 & & \\
\hline
\end{tabular}

\section{$P$. pungens}

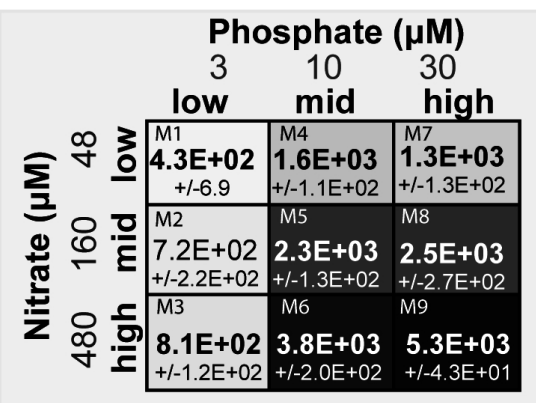

Pp1

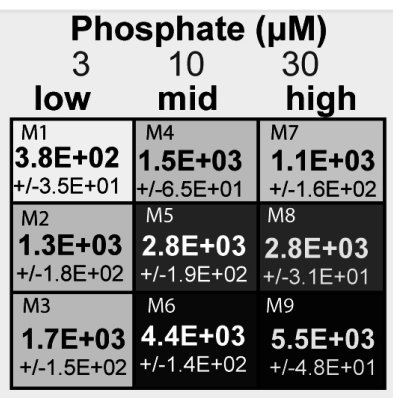

Pp2

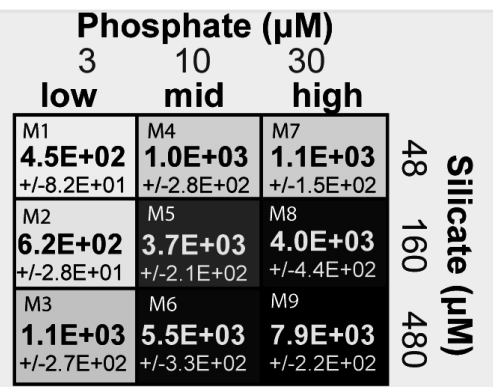

Pp3

Fluorescence 
A)

$P$. australis

P. fraudulenta

P. pungens

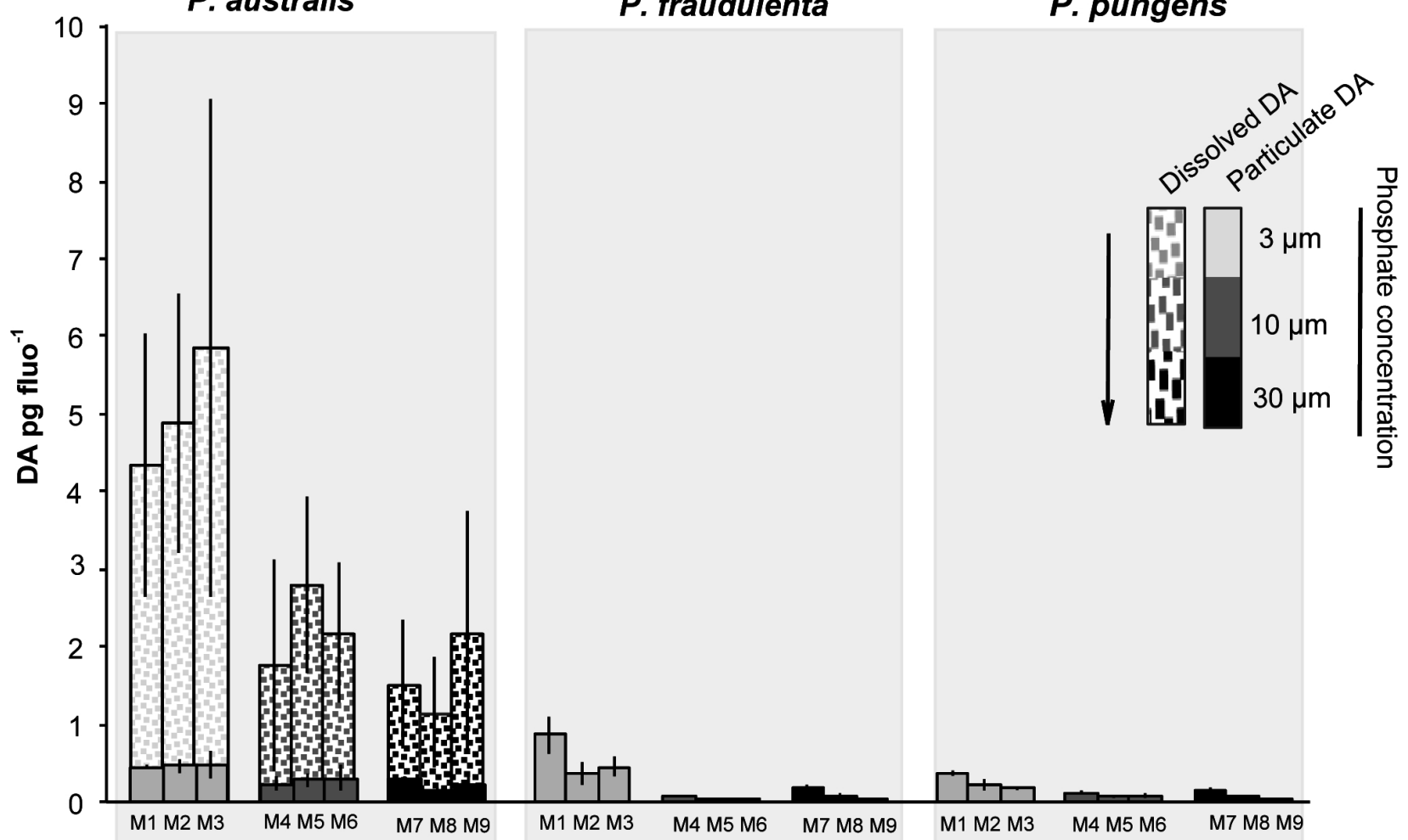

B)

Particulate DA
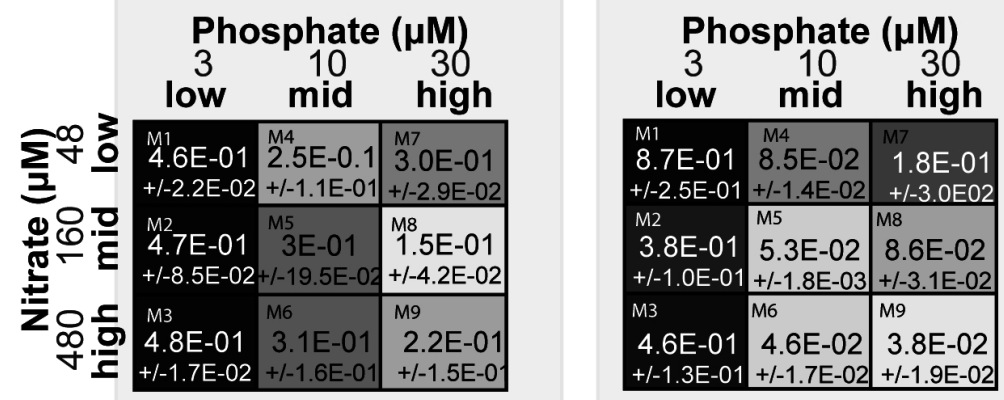

Phosphate ( $\mu \mathrm{M})$

low mid high

\begin{tabular}{|c|c|c|}
\hline $\begin{array}{l}\text { M1 } \\
3.7 \mathrm{E}-01 \\
+/-2.3 \mathrm{E}-02\end{array}$ & $\begin{array}{c}4 \\
1.3 \mathrm{E}-01 \\
+/-1.8 \mathrm{E}-02\end{array}$ & $\begin{array}{c}1.6 \mathrm{E}-01 \\
+/-2.9 \mathrm{E}-02\end{array}$ \\
\hline $\begin{array}{l}\text { M2 } \\
2.3 \mathrm{E}-01 \\
+/-7.6 \mathrm{E}-02\end{array}$ & $\begin{array}{l}\mathrm{M} 5 \\
7.6 \mathrm{E}-02 \\
+/-1.4 \mathrm{E}-02\end{array}$ & $\begin{array}{l}\mathrm{M} 8 \\
7.8 \mathrm{E}-02 \\
+/-1.6 \mathrm{E}-02\end{array}$ \\
\hline M3 & M6 & M9 \\
\hline $\begin{array}{r}1.9 \mathrm{E}-01 \\
+/-2.4 \mathrm{E}-02 \\
\end{array}$ & $\begin{array}{r}8.6 \mathrm{E}-02 \\
+-2.2 \mathrm{E}-02 \\
\end{array}$ & $\begin{array}{r}4.7 \mathrm{E}-02 \\
+/-1.8 \mathrm{E}-02 \\
\end{array}$ \\
\hline
\end{tabular}

\section{Dlissolved DA}

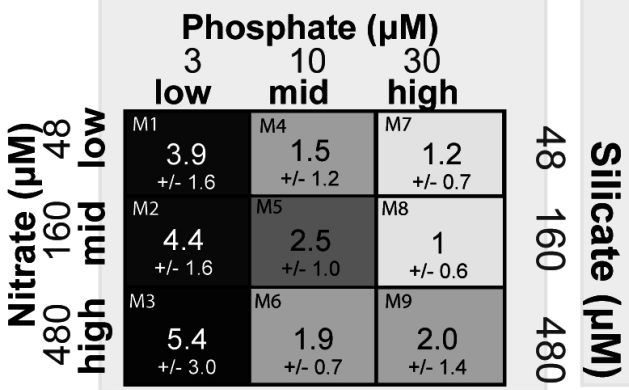

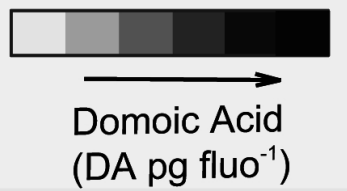




\section{P. australis}

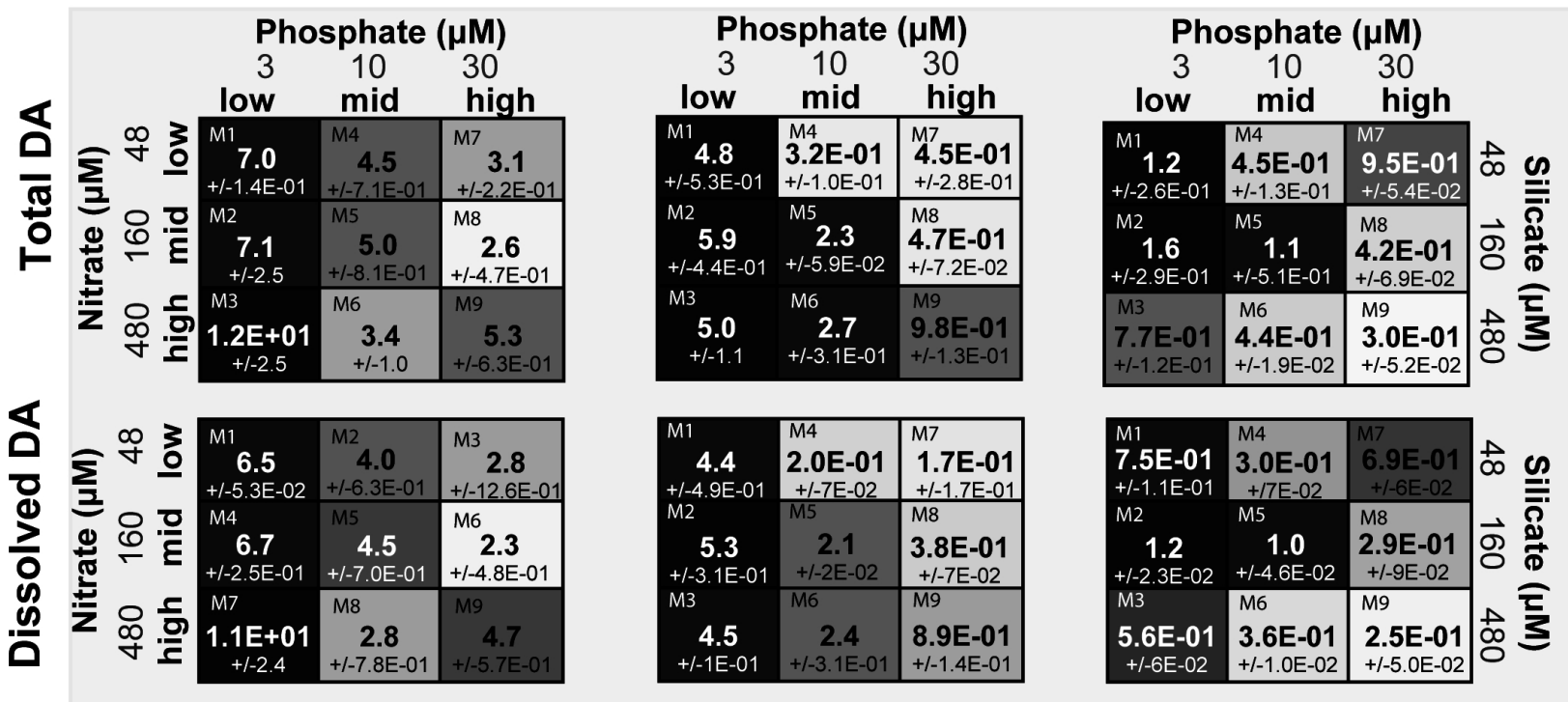

Pa1

Pa2

Pa3

\section{P. fraudulenta}

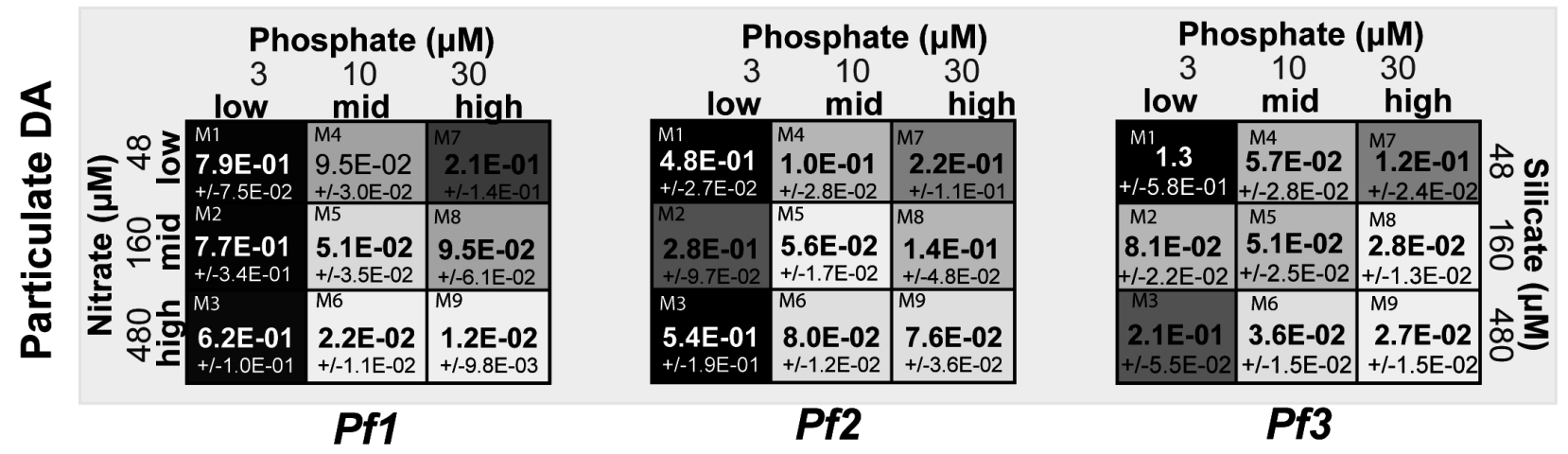

\section{P. pungens}

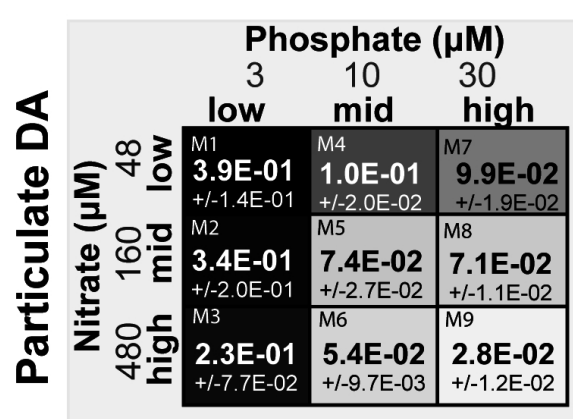

Pp1
Phosphate ( $\mu \mathrm{M})$

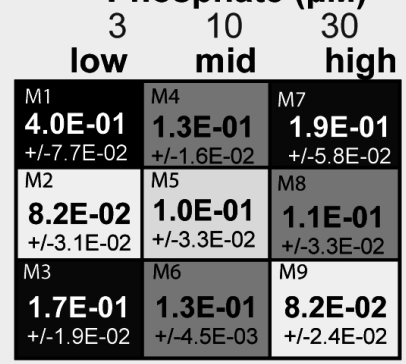

Pp2
Phosphate ( $\mu \mathrm{M})$

\begin{tabular}{|c|c|c|c|}
\hline 3 & $\begin{array}{l}10 \\
\text { mid }\end{array}$ & $\begin{array}{l}30 \\
\text { high }\end{array}$ & \\
\hline $\begin{array}{l}\mathrm{M} 1 \\
.2 \mathrm{E}-01 \\
i-4.1 \mathrm{E}-02\end{array}$ & $\begin{array}{l}44 \\
1.6 E-01 \\
+/-5.3 E-02\end{array}$ & $\begin{array}{l}\text { M7 } \\
1.8 E-01 \\
+/-5.9 E-02\end{array}$ & \\
\hline $\begin{array}{l}M 2 \\
\text { 2.6E-01 } \\
+/-5.3 \mathrm{E}-02\end{array}$ & $\begin{array}{l}\text { M5 } \\
\mathbf{5 . 4 E}-\mathbf{0 2} \\
+/-6.3 \mathrm{E}-03\end{array}$ & $\begin{array}{l}\text { M8 } \\
\mathbf{5 . 4 E}-02 \\
+--6.8 \mathrm{E}-03\end{array}$ & \\
\hline $\mathrm{M}$ & M6 & & \\
\hline $\begin{array}{r}1.5 E-01 \\
+/-6.2 E-02\end{array}$ & $\begin{array}{l}7.4 \mathrm{E}-02 \\
+/-1.7 \mathrm{E}-02\end{array}$ & $\begin{array}{l}3.1 \mathrm{E}-02 \\
+/-7.9 \mathrm{E}-03\end{array}$ & \\
\hline
\end{tabular}

\section{Pp3}

$\overrightarrow{\text { Fluorescence }}$ 
Supplementary Figure 1. Growth curves ( $\log 2$ fluorescence) for each of the nine assayed strains. Each panel corresponds to a strain. Each curve indicates the mean of three replicate assays. Media with low, medium, and high initial phosphate concentrations are in red, green and blue, respectively. Media with low, medium, and high initial nitrate and silicate concentrations are in full, dashed and dotted lines, respectively

Supplementary Figure 2. Cell abundance versus fluorescence units plots. To be able to use fluorescence as a proxy for growth we first looked at the relationship between number of cells and fluorescence at collection time (i.e at collection time: stationary phase). Overall relationship number of cells versus fluorescence at stationary phase plot a) for all species studied $\left(\mathrm{r}^{2}=0,71\right)$. b) for each species studied separately $\left(\mathrm{r}^{2}=0,82, \mathrm{r}^{2}=0,79\right.$ and $\mathrm{r}^{2}=0,70$ for P.pungens P.fraudulenta and P.australis respectively).

Supplementary Figure 3. Fluorescence at collection time (stationary phase) for the 3 species of Pseudo-nitzschia studied. Heat matrix correspond to the 9 different mediums, with different nutrient concentrations and P and N_Si levels as in Figure 1: where grey shades correspond to low to high fluorescence values. Average units of fluorescence as well as standard errors are indicated.

Supplementary Figure 4. Fluorescence at collection time (stationary phase), for the 9 strains of Pseudo-nitzschia studied and 9 medias. Heat matrix represent low to high fluorescence fallowing clear to darker shades of grey. Average units of fluorescence as well as standard errors are indicated. 
Supplementary Figure 5. Domoic acid (DA) concentrations per unit of fluorescence (pg fluorescence ${ }^{-1}$ ) at stationary phase for the 3 species of Pseudo-nitzschia studied (all strains combined) under different medias. A) Shows DA concentrations of the different species assigned to different phosphate concentrations (low, medium and high) corresponding to different grey shades. B) Heat matrix to show values, where grey shades represent low to high concentration of DA. Average DA and standard errors are indicated for each media.

Supplementary Figure 6. Domoic acid concentrations per unit of fluorescence at stationary phase for the 9 strains of Pseudo-nitzschia studied and 9 medias. Heat matrix represent low to high DA unit of fluorescence ${ }^{-1}$ following clear to darker shades of grey. Average DA fluorescence ${ }^{-1}$ as well as standard errors are indicated. 
Table 1. Cultures of Pseudo-nitzschia spp. used in the present study (nb: the collection references of the strains have also been added to enable comparisons with other studies, and the experiment started on $13^{\text {th }}$ august 2015). (A) stands for strains isolated in the Atlantic and (EC) for strains from the English Channel.

\begin{tabular}{lccccc}
\hline Species & $\begin{array}{c}\text { Collection } \\
\text { reference }\end{array}$ & $\begin{array}{c}\text { Name } \\
\text { present } \\
\text { study }\end{array}$ & $\begin{array}{c}\text { Collection } \\
\text { date }\end{array}$ & Station & $\begin{array}{c}\text { GPS Coordinates } \\
\text { (approximative) }\end{array}$ \\
\hline P.australis & IFR-PAU-010 & Pa1 & $14 / 07 / 15$ & Ouessant (A) & $48.449511 ;-5.108088$ \\
& & & Anse de Dinan, & \\
P. australis & P1D2 & Pa2 & $28 / 03 / 14$ & Camaret-sur-Mer & $48.225679 ;-4.563602$ \\
& & & & (A) & \\
$P$. australis & P6B3 & Pa3 & $04 / 04 / 14$ & Môle St Anne, & $48.358573 ;-4.551193$ \\
$P$. fraudulenta & PNfra2 & Pf1 & $24 / 08 / 11$ & Cabourg (EC) & $49.302888 ;-0.103549$ \\
$P$. fraudulenta & PNfra29 & Pf2 & $18 / 09 / 11$ & Cabourg (EC) & $49.302888 ;-0.103549$ \\
$P$. fraudulenta & PNfra31 & Pf3 & $11 / 07 / 11$ & COMOR 41(EC) & $49.414444 ;-0.408889$ \\
$P$. pungens & PNpun47 & Pp1 & $24 / 08 / 11$ & Cabourg (EC) & $49.302888 ;-0.103549$ \\
$P$. pungens & PNpun66 & Pp2 & $29 / 05 / 12$ & Ouistreham (EC) & $49.290574 ;-0.246028$ \\
$P$. pungens & PNpun102 & Pp3 & $21 / 08 / 12$ & Luc sur Mer (EC) & $49.320109 ;-0.351193$ \\
\hline
\end{tabular}


Table 2. Statistical results. ANOVA tests for cell density and domoïc acid concentration (TDA: total domoïc acid; PDA: Particulate domoïc acid). For these analyses a $\log 10$ transformation was used. For p-values $<0.05$. effect sizes (proportion of the variance explained by the factor) are reported. Significant $\mathrm{p}$ values are highlighted in italic bold.

\begin{tabular}{|c|c|c|c|c|c|c|}
\hline$\frac{\frac{n}{n}}{\frac{n}{n}}$ & $\begin{array}{c}\text { ANOVA Test : } \\
\text { Phosphate and Nitrate_Silicate levels }\end{array}$ & $\begin{array}{l}\text { Effect } \\
\text { size }\end{array}$ & Df & $\begin{array}{l}\text { Sum of } \\
\text { Sq }\end{array}$ & $\mathbf{F}$ & $P$-value \\
\hline 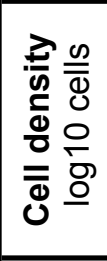 & $\begin{array}{l}\text { (Species*P levels)+(Species*N_Si levels) } \\
\text { Species } \\
\text { P levels } \\
\text { N_Si levels } \\
\text { Species: P levels } \\
\text { Species: N_Si levels } \\
\text { Residuals }\end{array}$ & $\begin{array}{c}0.1 \\
0.37 \\
0.14 \\
0.03 \\
0.04\end{array}$ & $\begin{array}{c}2 \\
2 \\
2 \\
4 \\
4 \\
66\end{array}$ & $\begin{array}{l}1.725 \\
6.170 \\
2.234 \\
0.516 \\
0.636 \\
5.179 \\
\end{array}$ & $\begin{array}{c}10.989 \\
39.316 \\
14.236 \\
1.646 \\
2.026\end{array}$ & $\begin{array}{c}7.6 e-05 \\
5.71 e-12 \\
7.24 e-06 \\
0.173 \\
0.101\end{array}$ \\
\hline 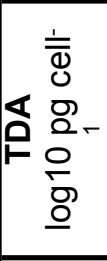 & $\begin{array}{l}\text { (Species*P levels)+(Species*N_Si levels) } \\
\text { Species } \\
\text { P levels } \\
\text { N_Si levels } \\
\text { Species: P levels } \\
\text { Species: N_Si levels } \\
\text { Residuals }\end{array}$ & $\begin{array}{l}0.59 \\
0.14 \\
0.02 \\
0.02 \\
0.03\end{array}$ & $\begin{array}{c}2 \\
2 \\
2 \\
4 \\
4 \\
66\end{array}$ & $\begin{array}{c}29.770 \\
7.09 \\
0.922 \\
0.833 \\
1.297 \\
10.303 \\
\end{array}$ & $\begin{array}{c}95.349 \\
22.708 \\
2.953 \\
1.334 \\
2.077\end{array}$ & $\begin{array}{c}<2 e-16 \\
3.13 e-08 \\
0.059 \\
0.266 \\
0.094\end{array}$ \\
\hline 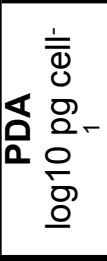 & $\begin{array}{l}\text { (Species*Plevels)+(Species*N_Silevels) } \\
\text { Species } \\
\text { Plevels } \\
\text { N_Si levels } \\
\text { Species: P levels } \\
\text { Species: N_Si levels } \\
\text { Residuals }\end{array}$ & $\begin{array}{l}0.25 \\
0.27 \\
0.07 \\
0.05 \\
0.03\end{array}$ & $\begin{array}{c}2 \\
2 \\
2 \\
4 \\
4 \\
66\end{array}$ & $\begin{array}{l}5.572 \\
5.992 \\
1.538 \\
0.945 \\
0.565 \\
7.492 \\
\end{array}$ & $\begin{array}{c}24.544 \\
26.395 \\
6.776 \\
2.081 \\
1.244\end{array}$ & $\begin{array}{c}1.07 e-08 \\
3.78 e-09 \\
0.00211 \\
0.093 \\
0.301\end{array}$ \\
\hline
\end{tabular}


Supplementary Table 1. Total days of growth and on stationary phase prior to collection for each strain in each of the nine mediums of this study

\begin{tabular}{|c|c|c|c|c|}
\hline Species & Strain & Media & $\begin{array}{c}\text { Days in } \\
\text { stationary phase }\end{array}$ & $\begin{array}{l}\text { Total days of } \\
\text { growth }\end{array}$ \\
\hline \multirow{27}{*}{ 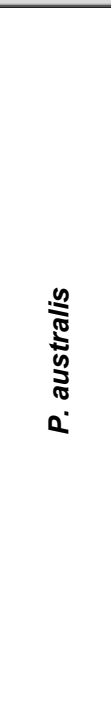 } & \multirow{9}{*}{$\bar{\sigma}$} & M1 & 7 & 13 \\
\hline & & M2 & 7 & 13 \\
\hline & & $\mathrm{M} 3$ & 7 & 13 \\
\hline & & M4 & 7 & 13 \\
\hline & & M5 & 7 & 13 \\
\hline & & M6 & 7 & 13 \\
\hline & & M7 & 7 & 13 \\
\hline & & M8 & 7 & 13 \\
\hline & & M9 & 7 & 13 \\
\hline & \multirow{9}{*}{ ชี } & M1 & 6 & 15 \\
\hline & & M2 & 7 & 15 \\
\hline & & M3 & 7 & 13 \\
\hline & & M4 & 7 & 13 \\
\hline & & M5 & 7 & 13 \\
\hline & & $\mathrm{M} 6$ & 7 & 13 \\
\hline & & M7 & 7 & 13 \\
\hline & & M8 & 7 & 13 \\
\hline & & M9 & 7 & 15 \\
\hline & \multirow{9}{*}{ ָூర } & M1 & 7 & 13 \\
\hline & & M2 & 5 & 15 \\
\hline & & M3 & 7 & 13 \\
\hline & & M4 & 5 & 13 \\
\hline & & M5 & 5 & 15 \\
\hline & & M6 & 5 & 13 \\
\hline & & M7 & 5 & 13 \\
\hline & & M8 & 5 & 15 \\
\hline & & M9 & 7 & 15 \\
\hline \multirow{27}{*}{ 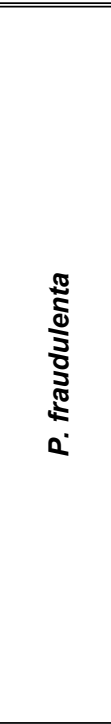 } & \multirow{9}{*}{ 兵 } & M1 & 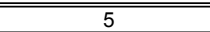 & 111 \\
\hline & & M2 & 5 & 11 \\
\hline & & M3 & 5 & 13 \\
\hline & & M4 & 5 & 14 \\
\hline & & M5 & 4 & 14 \\
\hline & & M6 & 4 & 13 \\
\hline & & M7 & 4 & 13 \\
\hline & & M8 & 4 & 13 \\
\hline & & M9 & 5 & 13 \\
\hline & & M1 & 5 & 11 \\
\hline & & M2 & 5 & 11 \\
\hline & & M3 & 7 & 13 \\
\hline & & M4 & 7 & 14 \\
\hline & $\stackrel{0}{0}$ & M5 & 5 & 13 \\
\hline & & M6 & 5 & 13 \\
\hline & & M7 & 7 & 13 \\
\hline & & M8 & 5 & 13 \\
\hline & & M9 & 4 & 10 \\
\hline & & M1 & 5 & 11 \\
\hline & & M2 & 5 & 14 \\
\hline & & M3 & 5 & 13 \\
\hline & & M4 & 4 & 14 \\
\hline & $\frac{6}{0}$ & M5 & 5 & 15 \\
\hline & & M6 & 4 & 13 \\
\hline & & M7 & 5 & 13 \\
\hline & & M8 & 4 & 14 \\
\hline & & M9 & 5 & 13 \\
\hline & & M1 & 7 & 13 \\
\hline & & M2 & 9 & 15 \\
\hline & & M3 & 9 & 15 \\
\hline & & M4 & 9 & 15 \\
\hline & 20 & M5 & 9 & 15 \\
\hline & & M6 & 7 & 13 \\
\hline & & M7 & 7 & 13 \\
\hline & & M8 & 9 & 15 \\
\hline & & M9 & 9 & 15 \\
\hline & & M1 & 7 & 13 \\
\hline & & M2 & 9 & 15 \\
\hline$\stackrel{2}{=}$ & & M3 & 9 & 15 \\
\hline 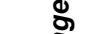 & & M4 & 9 & 15 \\
\hline 5 & 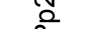 & M5 & 7 & 15 \\
\hline จ & & $\mathrm{M} 6$ & 5 & 13 \\
\hline $0^{\circ}$ & & M7 & 7 & 13 \\
\hline & & M8 & 7 & 15 \\
\hline & & M9 & 7 & 15 \\
\hline & & M1 & 7 & 13 \\
\hline & & M2 & 9 & 15 \\
\hline & & M3 & 9 & 15 \\
\hline & & M4 & 9 & 15 \\
\hline & ח & M5 & 7 & 15 \\
\hline & 口 & M6 & 6 & 13 \\
\hline & & M7 & 7 & 13 \\
\hline & & M8 & 7 & 15 \\
\hline & & M9 & 9 & 15 \\
\hline
\end{tabular}


Supplementary Table 2. Statistical results from fluorescence data. ANOVA tests for fluorescence and domoïc acid concentration (TDA: total domoïc acid; PDA: Particulate domoï acid). For p-values $<0.05$ effect sizes (proportion of the variance explained by the factor) are reported. Significant $\mathrm{p}$ values are highlighted in italic bold.

\begin{tabular}{|c|c|c|c|c|c|c|}
\hline$\frac{\frac{n}{n}}{\frac{\pi}{n}}$ & $\begin{array}{c}\text { ANOVA Test: } \\
\text { Phosphate and Nitrate_Silicate } \\
\text { levels }\end{array}$ & $\begin{array}{c}\text { Effect } \\
\text { size }\end{array}$ & Df & Sum of Sq & $\mathbf{F}$ & $P$-value \\
\hline 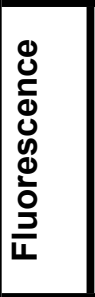 & $\begin{array}{l}\text { (Species*P levels)+(Species*N_Si levels) } \\
\text { +Error(Strain) } \\
\text { Species } \\
\text { P levels } \\
\text { N_Si levels } \\
\text { Species: P levels } \\
\text { Species: N_Si levels } \\
\text { Residuals }\end{array}$ & $\begin{array}{l}0.06 \\
\mathbf{0 . 2 9 1} \\
\mathbf{0 . 2 2 5} \\
\mathbf{0 . 0 5 3} \\
\mathbf{0 . 0 6 2}\end{array}$ & $\begin{array}{c}2 \\
2 \\
2 \\
4 \\
4 \\
222 \\
\end{array}$ & $\begin{array}{c}34810989 \\
184432785 \\
143009670 \\
33665195 \\
39431540 \\
163915784\end{array}$ & $\begin{array}{c}2.958 \\
124.89 \\
96.84 \\
11.40 \\
13.35\end{array}$ & $\begin{array}{c}0.128 \\
<2 e-16 \\
<2 e-16 \\
1.97 e-08 \\
9.14 e-10\end{array}$ \\
\hline 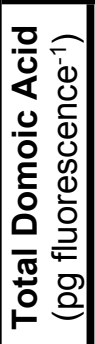 & $\begin{array}{l}\text { (Species*P levels)+(Species*N_Si levels) } \\
\text { +Error(Strain) } \\
\text { Species } \\
\text { P levels } \\
\text { N_Si levels } \\
\text { Species: P levels } \\
\text { Species: N_Si levels } \\
\text { Residuals }\end{array}$ & $\begin{array}{l}0.516 \\
0.139 \\
0.019 \\
0.023 \\
0.026\end{array}$ & $\begin{array}{r}2 \\
2 \\
2 \\
4 \\
4 \\
222\end{array}$ & $\begin{array}{l}81.32 \\
21.92 \\
3 \\
3.61 \\
4.04 \\
31.85\end{array}$ & $\begin{array}{c}20.41 \\
76.393 \\
10.466 \\
6.284 \\
7.032\end{array}$ & $\begin{array}{c}0.0021 \\
<2 e-16 \\
4.53 e-05 \\
8.30 e-05 \\
2.39 e-05\end{array}$ \\
\hline 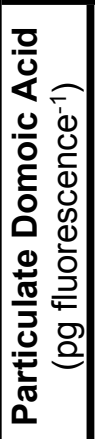 & $\begin{array}{l}\text { (Species*P levels)+(Species*N_Si levels) } \\
\text { +Error(Strain) } \\
\text { Species } \\
\text { P levels } \\
\text { N_Si levels } \\
\text { Species: P levels } \\
\text { Species: N_Si levels } \\
\text { Residuals }\end{array}$ & $\begin{array}{l}0.11 \\
0.253 \\
0.064 \\
0.058 \\
\mathbf{0 . 0 2 6}\end{array}$ & $\begin{array}{l}2 \\
2 \\
2 \\
4 \\
4\end{array}$ & $\begin{array}{c}7.969 \\
18.83 \\
4.77 \\
4.3 \\
1.94\end{array}$ & $\begin{array}{c}5.058 \\
65.7 \\
16.656 \\
7.501 \\
3.393\end{array}$ & $\begin{array}{c}0.0516 \\
<2 e-16 \\
1.82 e-07 \\
1.10 e-05 \\
0.0102\end{array}$ \\
\hline
\end{tabular}

* data transformed to $\log 10$ 
Supplementary Table 3. Statistical results of fluorescence within each Pseudo-nitzschia species (intra-species variation). ANOVA tests for fluorescence and domoïc acid concentration (TDA: total domoïc acid; PDA: Particulate domoïc acid). For p-values $<0.05$ effect sizes (proportion of the variance explained by the factor) are reported. Significant $p$ values are highlighted in italic bold.

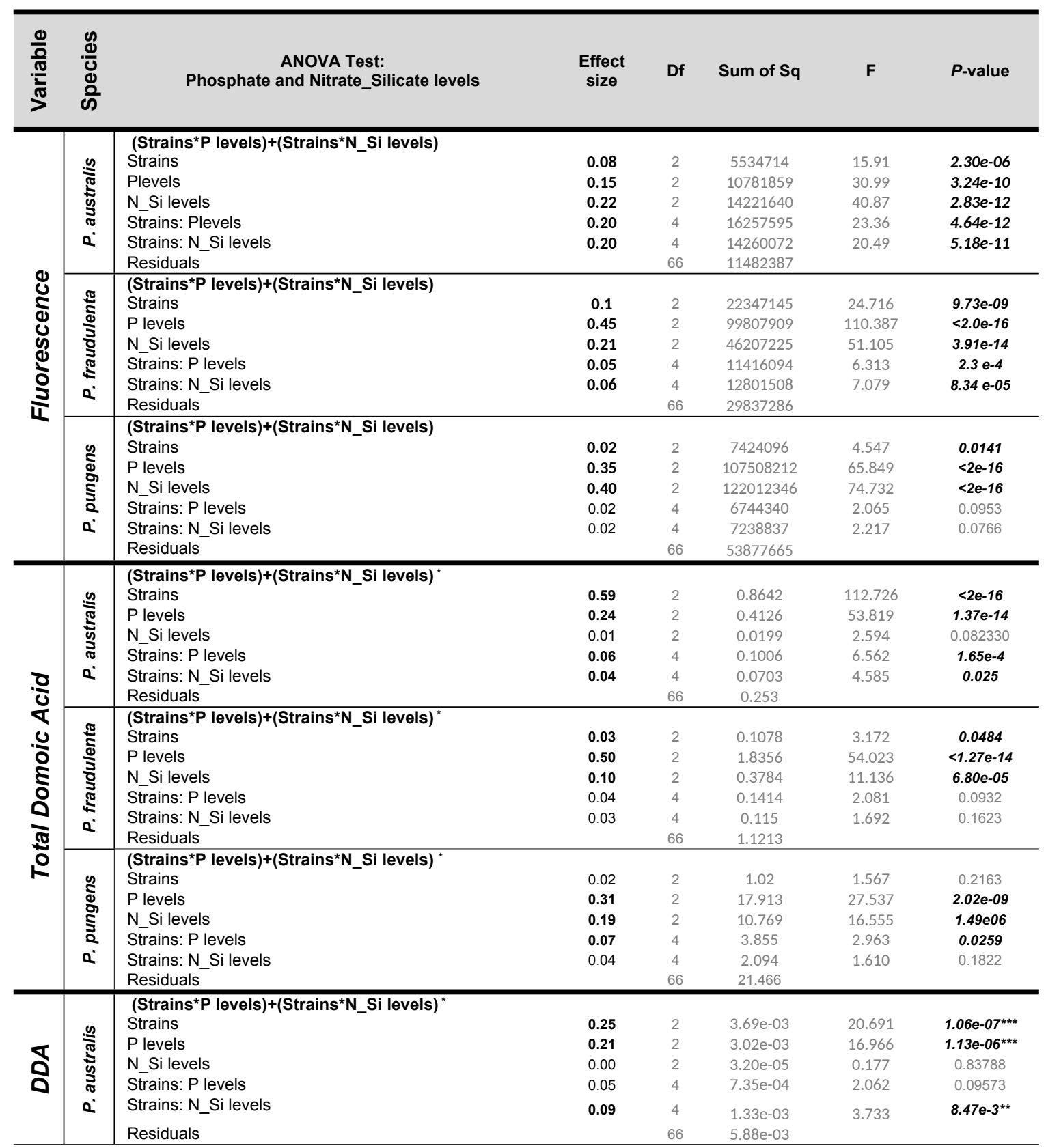

* data transformed with "powertransform" application from Car package in R 